\title{
A Synoptic Survey of Trace Metals in Bottom Sediments of the
}

\section{Willamette River, Oregon}

River-Quality Assessment of the Willamette River Basin, Oregon

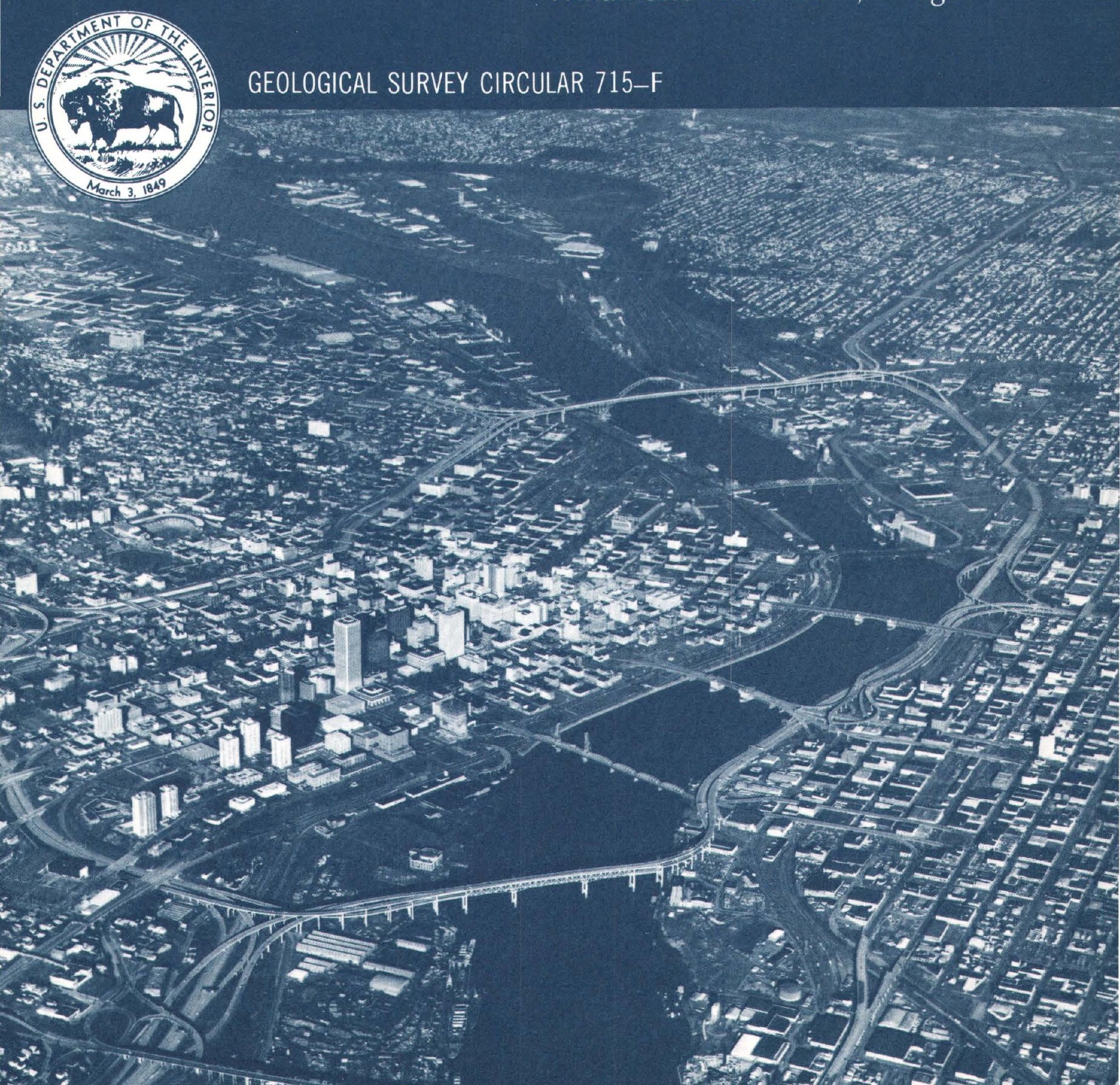





\section{A Synoptic Survey of Trace Metals in Bottom Sediments of the Willamette River, Oregon}

By David A. Rickert, Vance C. Kennedy, Stuart W. McKenzie, and Walter $G$. Hines

RIVER-QUALITY ASSESSMENT OF THE WILLAMETTE RIVER BASIN, OREGON

GEOLOGICAL SURVEY CIRCULAR 715-F 


\section{United States Department of the Interior}

THOMAS S. KLEPPE, Secretary

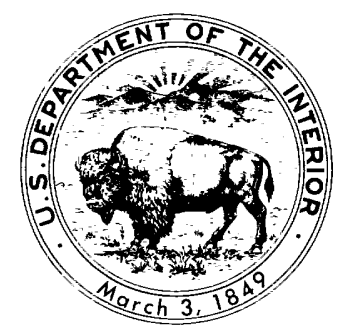

\section{Geological Survey}

\section{E. McKelvey, Director}

Rickert, David A., 1940-

A Synoptic survey of trace metals in bottom sediments of the Willamette River, Oregon. (Riverquality assessment of the Willamette River Basin, Oregon)

(Geological Survey Circular 715-F)

Bibliography: p. 21-22

Supt. of Docs. no.: I $19.4 / 2: 715-\mathrm{F}$

1. Trace elements-Analysis. 2. Sediments (Geology)-Oregon-Willamette River. I. Rickert,

David A., 1940- II. Series. III. Series: United S tates Geological Survey Circular 715-F. QE75.C5 no. 715-F[QD139.T7] 557.3'08s[551.4'83'097953] 76-608335 


\section{FOREWORD}

The American public has identified the enhancement and protection of river quality as an important national goal, and recent laws have given this commitment considerable force. As a consequence, a considerable investment has been made in the past few years to improve the quality of the Nation's rivers. Further improvements will require substantial expenditures and the consumption of large amounts of energy. For these reasons, it is important that alternative plans for river-quality management be scientifically assessed in terms of their relative ability to produce environmental benefits. To aid this endeavor, this circular series presents a case history of an intensive river-quality assessment in the Willamette River basin, Oregon.

The series examines approaches to and results of critical aspects of riverquality assessment. The first several circulars describe approaches for providing technically sound, timely information for river-basin planning and management. Specific topics include practical approaches to mathematical modeling, analysis of river hydrology, analysis of earth resources-river quality relations, and development of data-collection programs for assessing specific problems. The later circulars describe the application of approaches to existing or potential river-quality problems in the Willamette River basin. Specific topics include maintenance of high-level dissolved oxygen in the river, effects of reservoir release patterns on downstream river quality, algal growth potential, distribution of toxic metals, and the significance of erosion potential to proposed future land and water uses.

Each circular is the product of a study devoted to developing resource information for general use. The circulars are written to be informative and useful to informed laymen, resource planners, and resource scientists. This design stems from the recognition that the ultimate success of river-quality assessment depends on the clarity and utility of approaches and results as well as their basic scientific validity.

Individual circulars will be published in an alphabetical sequence in the Geological Survey Circular 715 series entitled "River-Quality Assessment of the Willamette River Basin, Oregon."

J. S. Cragwall, Jr. Chief Hydrologist 
Cover: Willamette River as it winds through Portland, Oregon. Photograph taken by Hugh Ackroyd. 


\section{CONTENTS}

\begin{tabular}{|c|c|}
\hline Page & Page \\
\hline F1 & Examination of study approaches-Continued \\
\hline Introduction & Fractionation of samples at $20 \mu \mathrm{m}$ \\
\hline The Willamette River basin & Distinction between natural background and follution \\
\hline Geologic overview & Zinc \\
\hline Willamette River morphology & Lead ...... \\
\hline Possible sources of trace metals & Copper \\
\hline Sampling $-1-1-1-1$ & Chromium _....... \\
\hline Sampling medium & Mercury \\
\hline Sampling approach & Cadmium \\
\hline Sampling locations & Fourth Lake \\
\hline Laboratory procedures and analytical results & Comparison of results to trace-metal concentrations in \\
\hline Physical procedures & d soils \\
\hline Analysis of metals & Summary and conclusions \\
\hline 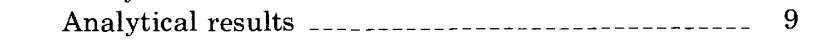 & Acknowledgments \\
\hline Examination of study approaches & Glossary of selected terms \\
\hline Sampling from the visual center of flow & References \\
\hline
\end{tabular}

\section{ILLUSTRATIONS}

Figure 1. Map of the Willamette River basin, Oreg., showing mining areas and sediment-sampling sites in the Upstream Reach _...-

2. Map and diagram representing the Willamette River, Oreg., showing distinctive hydrologic reaches and elevation profile

3. Map showing sediment-sampling sites in the Tidal Reach and the Newberg Pool

4. Graphs showing the relation of trace-metal concentrations in $<2$-mm materials to the percentage by weight of $<20-\mu \mathrm{m}$ materials, (A) copper, (B) lead, (C) zinc

5. Normal-probability plots of zinc concentrations in $<20-\mu \mathrm{m}$ materials, (A) all Willamette River basin samples, (B) unpolluted samples _

6. Normal-probability plots of trace-metal concentrations in $<20-\mu \mathrm{m}$ materials, (A) lead, (B) copper

7. Normal-probability plots of trace-metal concentrations in $<20-\mu \mathrm{m}$ materials, (A) chromium, (B) mercury ---- 17

\section{TABLES}

TABLE 1. Selected physical characteristics of the main stem Willamette River, Oreg

2. Possible sources of trace metals in the Willamette River system

3. Concentrations of trace metals in bottom sediments from the Willamette River and adjacent waters

4. Geographic distribution of trace-metal concentrations in the $<20-\mu \mathrm{m}$ materials of bottom sediments from the Willamette River and adjacent waters _

5. Comparison of trace-metal concentrations in center-of-flow samples to cross-sectional samples for tr $\because<20-\mu \mathrm{m}$ materials - -

6. Concentrations of trace metals in Fourth Lake

7. Summary data from normal-probability plots of trace-metal concentrations

8. Trace-metal concentrations in bottom sediments, rocks, and soils

9. Site descriptions and physical characteristics of bottom sediments from the Willamette River and adjacent waters -

10. Particle-size composition of bottom sediments from the Willamette River and adjacent waters

11. Checklist of element names and symbols 
TABLE 12 Concentrations of major elements in

13. Trace elements having concentrations in all sediment samples below detection limits of the emmission-

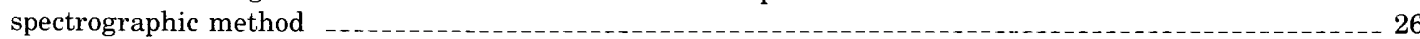

14. Concentrations of trace elements in $<20-\mu \mathrm{m}$ materials of bottom sediments from the Willamette $\mathrm{Kiver}$ and adjacent waters _.

15. Uses and sources of selected trace metals

\section{CONVERSION FACTORS}

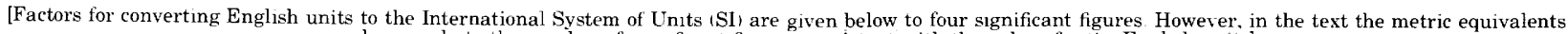
are shown only to the number of significant figures consistent with the values for the English units]

\section{English}

$\mathrm{ft}$ (feet)

$\mathrm{ft} / \mathrm{s}$ ( feet per second)

$\mathrm{ft} / \mathrm{mi}$ (feet per mile)

$\mathrm{ft}^{3 / \mathrm{s}}$ (cubic feet per second)

mi (miles)

$\mathrm{mi}^{2}$ (square miles)

ton (short, 2,000 lb)
Multiply by

$3.048 \times 10^{-1}$

$3.048 \times 10^{-1}$

$1.894 \times 10^{-1}$

$2.832 \times 10^{-2}$

1.609

2.590

$9.072 \times 10^{-1}$
Metrie $\lfloor S I$

$\mathrm{m}$ (metres)

$\mathrm{m} / \mathrm{s}$ (metres per second)

$\mathrm{m} / \mathrm{km}$ (metres per kilometre)

$\mathrm{m}^{3} / \mathrm{s}$ (cubic metres per second)

$\mathrm{km}$ (kilometres)

$\mathrm{km}^{2}$ (square kilometres)

$\mathrm{t}$ (tonne) 


\title{
A Synoptic Survey of Trace Metals in Bottom Sediments of the Willamette River, Oregon
}

\author{
By David A. Rickert, Vance C. Kennedy, Stuart W. McKenzie, \\ and Walter $\mathrm{G}$. Hines
}

\section{ABSTRACT}

During September 1973, 44 bottom sediment samples were collected to assess the concentration and distribution of trace metals in the Willamette River, Oreg. The specific objectives were to provide (1) baseline information for future comparison and (2) a basis for determining whether the analyzed metals were present in high enough concentrations to represent an ecological threat.

Aliquots of the 44 samples were size separated at 2 millimetres to exclude gravel-sized materials and at 20 micrometres $(\mu \mathrm{m})$ to obtain fractions containing the clay and fine silt materials. The $<20-\mu \mathrm{m}$ fractions and aliquots of each whole sample were then analyzed by atomic-absorption spectrophotometry and colorimetry for arsenic, cadmium, chromium, copper, lead, mercury, silver, and zinc. A separate aliquot of each $<20-\mu \mathrm{m}$ fraction was investigated by semiquantitative emission-spectrographic analysis to detect possible anomalous concentrations of 50 elements.

Trace-metal concentrations in the Willamette were generally indicative of a clean environment. The exceptions were a moderate enrichment of zinc, a slight enrichment of copper and lead, and pollution by several metals in an industrial slough. The zinc enrichment resulted primarily from zinc hydrosulfite used as a brightening agent in ground-wood pulp and paper mills. Upon orders from the Oregon Department of Environmental Quality, all mills will cease using zinc hydrosulfite by July 1977 . The lead enrichment appeared to result directly from urban drainage, but causes of the elevated copper levels were not apparent. Fourth Lake, an industrial slough near Albany, showed enrichment of 15 elements including uncommon metals such as zirconium, hafnium, yttrium, ytterbium, and tin. However, none of these metals was present in enriched concentrations at any of the downstream sites.

\section{INTRODUCTION}

Many materials discharged into river systems are toxic to aquatic organisms when present in critical concentrations. These materials include numerous trace metals (see "Glossary of Selected Terms") and manmade organic compounds such as insecticides, polychlorinated biphenyls (PCB's), herbicides, and certain industrial or- ganics. Even though such materials are usually discharged to rivers at subtoxic levels, many are capable of being concentrated at successive steps in aquatic food chains in a prosess called "biological magnification."

Review of industrial-discharge permits for the Willamette River basin indicates that there is very little possibility of toxic industrial organics entering the Willamette River. Furthermore, over the last 10 years, hard pesticides (such as DDT) have not been used in the basin for disease-vector control nor for widespread plantpest control. In contrast, there are several industrial sources of potentially toxic trace metals in addition to the metals that undoubtedly enter the river in urban runoff. Thus, if a toxicity problem occurred, it would probably result from the accumulation of trace metals.

Prior to this study, few data existed on the content of trace metals in the water, sediment, and food chains of the Willamette River. D ta were so sparse as to preclude even a preliminary assessment of whether metal concentrations were low, moderate, or critically high. To partly fill the void, this report presents information on the concentration and distribution of trace metals in the river-bottom sediments.

The objectives of this trace-metal reconnaissance were to provide (1) baseline information for future comparison and (2) a basis for determining whether the analyzed metals were present in high enough concentrations to rerresent an ecological threat.

The first goal was fully attainable, the second only partly, because scientists presently lack the ability to relate with confidence the concentrations of trace metals in river sediments to the potential for aquatic organism toxicit!r. The abil- 
ity to define such relationships will require intensive research on the modes and chemical forms of metal transport and on the processes of metal uptake and release by sediments and organisms. In addition, definitive information will be needed on the life cycles of aquatic organisms and on their physiological tolerances.

In the absence of definitive information on toxicity relationships, this circular presents a procedure for identifying those trace metals in bed sediments that are present in concentrations indicative of pollution. The procedure involves (1) physical separation of materials $<20-\mu \mathrm{m}$ in size from bulk sediment samples, (2) trace-metal analysis of the $<20-\mu \mathrm{m}$ materials, (3) examination of determined metal concentrations through use of probability plots, and (4) comparison of the concentrations with the metal contents of soils and rocks.

To establish a basis for collecting and assessing trace-metal data, the following section provides background information on the Willamette River basin.

\section{THE WILLAMETTE RIVER BASIN}

The Willamette River basin, a watershed of nearly $11,500 \mathrm{mi}^{2}\left(29,800 \mathrm{~km}^{2}\right)$ (fig. 1), is located in northwestern Oregon between the Cascade and Coast Ranges. Within the basin are the State's three largest cities, Portland, Salem, and Eugene, and approximately 1.4 million people, representing 70 percent of the State's population (1970 census). The Willamette River basin supports an economy based on timber, agriculture, industry, and recreation and contains extensive fish and wildlife habitats.

The Willamette River forms at the confluence of the Coast and Middle Forks near Eugene and flows northward for $187 \mathrm{mi}(300 \mathrm{~km})$ through the $3,500-\mathrm{mi}^{2}\left(9,100-\mathrm{km}^{2}\right)$ Willamette Valley floor. Tributaries of the Willamette include the Long Tom, Marys, Luckiamute, Yamhill, and Tualatin Rivers, which flow eastward from the Coast Range, and the McKenzie, Calapooia, Santiam, Molalla, and Clackamas Rivers, which flow westnorthwest from the Cascade Range. (See fig. 1.)

\section{GEOLOGIC OVERVIEW}

On the basis of physiography and geology, the Willamette River basin can be divided into three north-south provinces: the Cascade Kange, the Coast Range, and the interlying Willamette Valley (Willamette Basin Task Force, Apnendix A, 1969).

The volcanic rocks that compose tho Cascade Range can be divided into two major gyoups. The older group consists of basalt and ardesite together with volcanic debris. These rocks have been folded, faulted, and extensively altered. The younger rocks, which form the High Cascades, are derived from more recent basaltic and andesitic lava flows.

The mountains and foothills of the Ccast Range are formed largely by volcanic rocks and by marine sedimentary rocks derived from them. The older volcanic rocks, consisting of basaltic flows and volcanic debris, are interbetded with continental sedimentary rocks. The marine sedimentary rocks consist of sandstone, shale, and mudstone.

The Willamette Valley is an alluvicl lowland framed by the upland volcanic and sedimentary rocks. Much of the valley is covered by' sandy to silty terrace deposits that settled from water ponded in a great glaciofluvial lake. Most of the materials in these deposits originated from upstream areas of the Columbia River basin (Glenn, 1965). The alluvial deposits that border existing rivers were derived largely from the surrounding mountains. These deposits consist of interbedded layers of clay, silt, sand, and gravel.

\section{WILLAMETTE RIVER MORPHOLOGY}

The bed of the Willamette River drors from an altitude of $435 \mathrm{ft}(133 \mathrm{~m})$ at Eugene to slightly below mean sea level at Portland (fig. 2). The river comprises three distinctive reacles whose physical characteristics govern the hyc'raulics of flow and therefore the patterns of deposition, channel scour, and sediment transport.

The Upstream Reach (fig. 2 and takle 1), extending for $135 \mathrm{mi}(217 \mathrm{~km})$ from Eugene to above Newberg, is characterized by a meandering channel. The river is shallow and the bed is composed almost entirely of cobbles and gravel which during summer are covered with biological growth. During low-flow conditions, average stream velocity in the Upstream Reach is more than 7 times that of either of the two downstream reaches (table 1). During floods, velonities are 


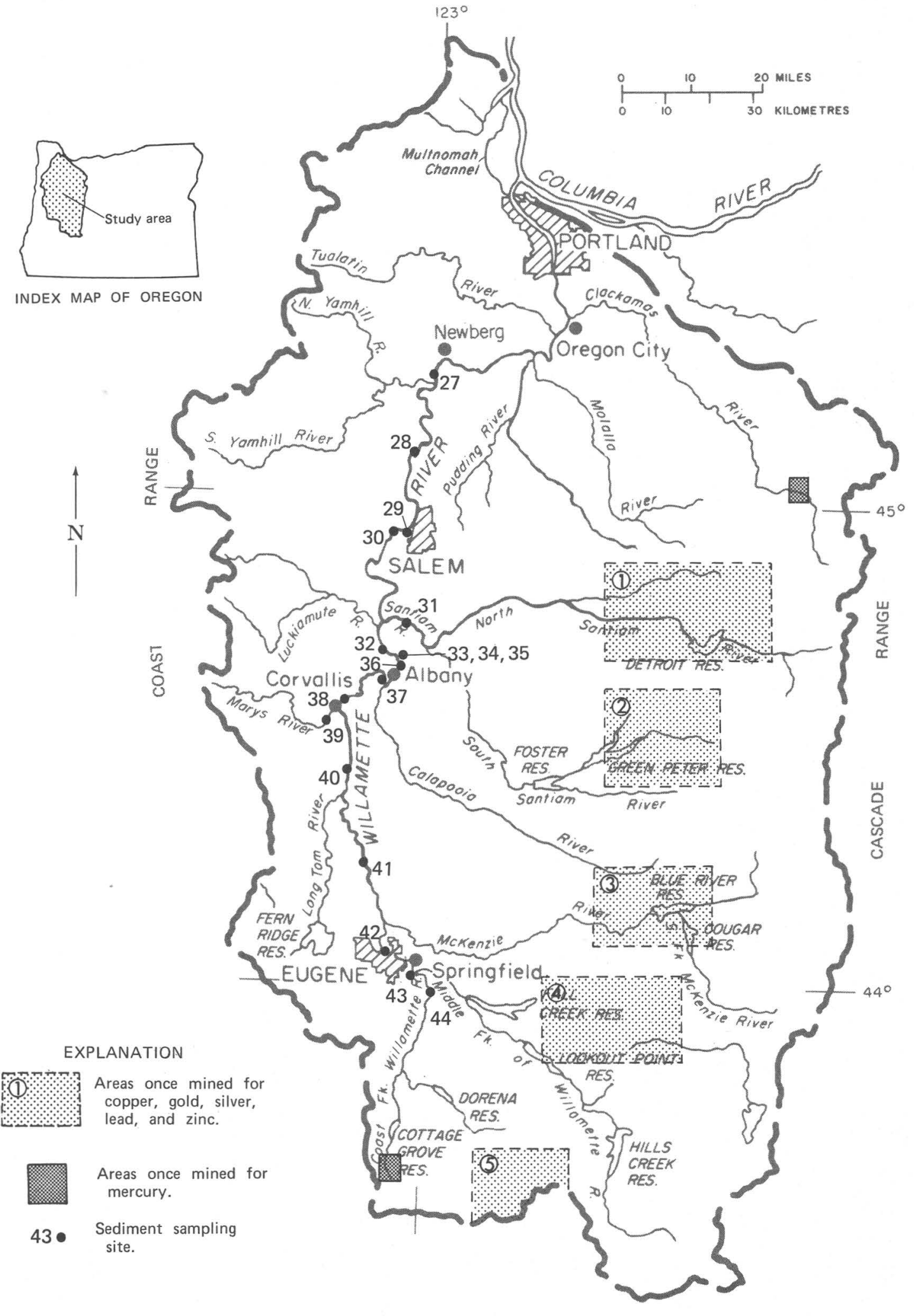

FIGURE 1.-Map of the Willamette River basin, Oreg., showing mining areas and sediment-sampling sites in the Upstream Reach (above the Newberg Pool). 


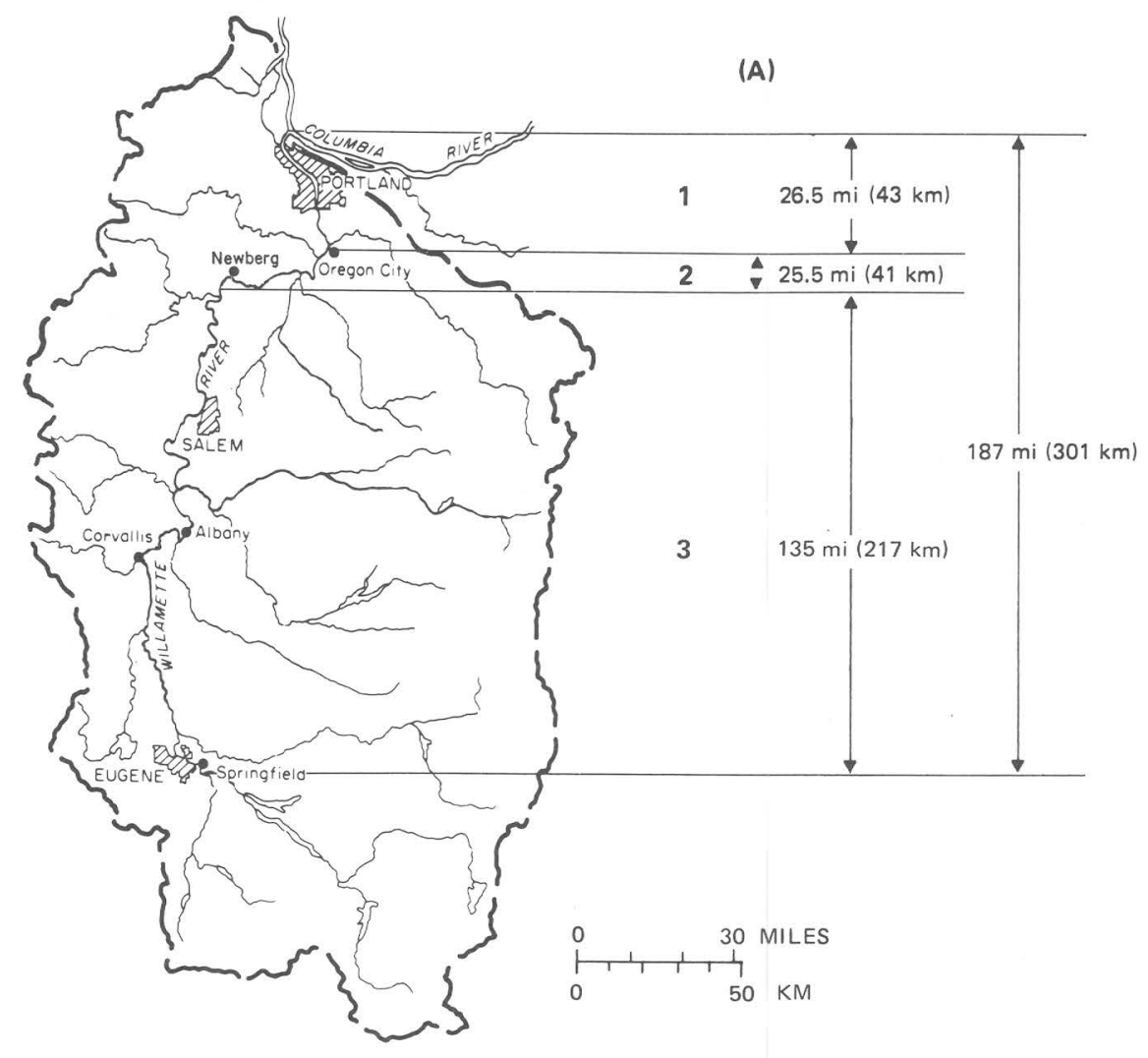

(B)

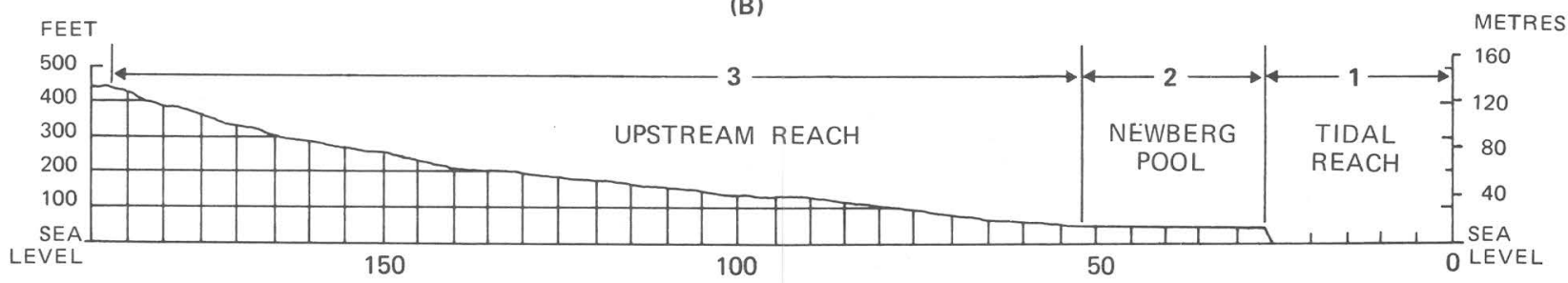

DISTANCE, IN RIVER MILES ABOVE MOUTH

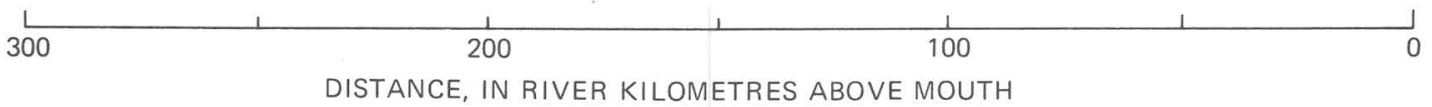

FIgURE 2.-Willamette River, Oreg. $A$, Distinctive hydrologic reaches. $B$, Elevation profile.

sufficiently high to transport large quantities of cobbles and gravel as bedload. Morphologically, this upstream section of the Willamette is an "eroding" reach.

The Newberg Pool extends for $25.5 \mathrm{mi}$ $(41.0 \mathrm{~km})$ from above Newberg to the Willamette Falls. The deep, slow-moving pool can be characterized hydraulically as a large stilling basin behind a weir (Willamette Falls). The pool is a depositional reach, as evidenced by the elevation profile (fig. 2), average low-flow velocity (table 1), and the presence of fine bottom sediments.

The Tidal Reach, covering the lower $26.5 \mathrm{mi}$ $(42.6 \mathrm{~km})$ of the river, is affected by tides and during spring and early summer by backwater from the Columbia River (Velz, 1961). The Tidal Reach is extensively dredged to maintain a $40-\mathrm{ft}$ (12-m) deep navigation channel from the mouth to about river mile (RM) 14, or river kilometre (RK) 22 . During the summer low-flow period, net downstream movement is relatively slow, but tidal effects cause flow reversals twice daily and 
TABLE 1.- Selected physical characteristics of the main stem Willamette River, Oreg.

[Characteristics refer to summer low-flow conditions of $6=10^{3} \mathrm{ft}^{3} / \mathrm{s}$ at Salem]

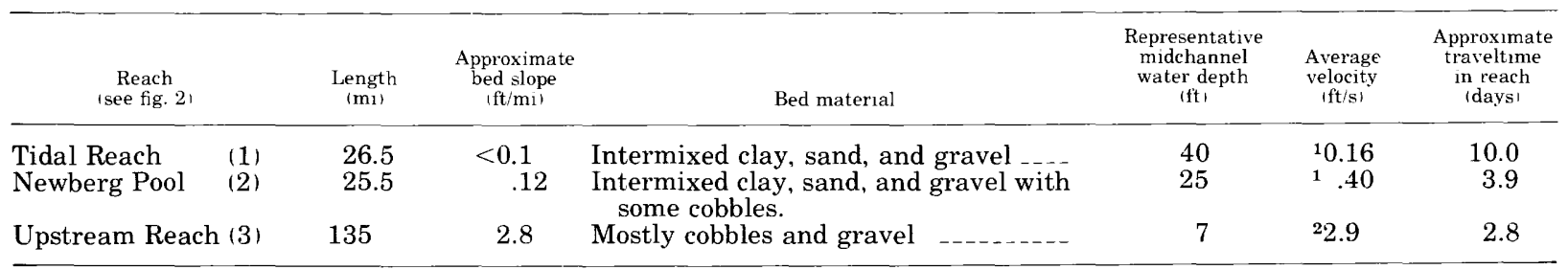

${ }^{2}$ Calculated by volume displacement method using channel cross-sectional data

${ }^{2}$ Calculated from dye study by U.S. Geological Survey $\uparrow$ Harris, 1968 เ.

large changes in velocity. Low-flow hydraulics are most complex in the lower $10 \mathrm{mi}(16 \mathrm{~km})$ where, depending on hourly changes in tide- and river-stage conditions, Willamette River water may move downstream or Columbia River water may move upstream. Owing to morphological characteristics and the hydraulic conditions, the subreach between RM's 10 and 3 is the primary depositional area of the Willamette River system.

\section{POSSIBLE SOURCES OF TRACE METALS}

Besides natural geological background, the possible sources of trace metals in the Willamette River basin include industrial activities, urban runoff, municipal waste-water discharges, and old mining areas. Table 2 shows the river-mile location on the Willamette of most known or potential sources of metals. The table also indicates the discharge locations of tributaries.

In the Portland metropolitan area, the land corridor along the Willamette is used for many industrial and shipping activities which represent possible direct sources of metals (table 2). In addition, the city of Portland is served by a combined sewerage system that during intense rainfall overflows into the Willamette carrying metals from raw sewage, various industries, and street runoff. (Dry weather flow is diverted via the municipal treatment plant to the Columbia River.) Moreover, between RM's 17 and 27.5, street runoff periodically enters the Willamette through a separate storm-drainage system.

Farther upstream, storm drainage and municipal secondary effluents represent additional trace-metal sources in other urban areas.

Pulp and paper production is a major industry of the Willamette River basin. For many years, zinc hydrosulfite has been used as a brightening agent in the ground-wood pulping process at three large mills (table 2). The three plants and their 1973 zinc loadings to the Willamette were
Publishers Paper Co. at Newberg (KM 49.2), 71 tons (64 t) (Zenon Rozycki, Publishers Paper, oral commun., 1975); Publishers Paper Co. at Oregon City (RM 28.0), 89 tons ( $81 \mathrm{t}$ ); and Crown Zellerbach Corp. at West Linn (RM 27.6), 74 tons (67 t) (Herman Amberg, Crown Zellerbach, oral commun., 1975). In compliance with orders of the Oregon Department of Environmental Quality, Publishers Paper switched to a nonzinc brightening agent at both plants in spring 1974, and Crown Zellerbach will switch by July 1977.

There are seven mineralized areas in the Willamette River basin which at one timo or another were commercially mined (Oregon Department of Geology and Mineral Industries, 1951; Willamette Basin Task Force, Appendix A, 1969). Mercury was once mined from the Black Butte area on the Coast Fork above Cottage Grove Reservoir and from the Oak Grove Fork area in the headwaters of the Clackamas River.

The five other areas were mined at various times for copper, gold, lead, silver, and zinc. The areas and their drainage trilutaries are (see fig. 1):

1. North Santiam district; tributary to the Santiam River.

2. Quartzville district; tributary to the Santiam River.

3. Blue River district; tributary to tho McKenzie River.

4. Fall Creek district; tributary to the Middle Fork Willamette.

5. Bohemia district; tributary to the Coast Fork Willamette.

No natural deposits of cadmium or chromium are known to exist in the Willamette River basin. No commercially exploitable source of arsenic exists, but high concentrations of this metal do occur in the ground water of Lane County at the southern end of the basin (Goldblatt and others, 1963). 
TABLE 2.-Possible sources of trace metals in the Willamette River system ${ }^{1}$

Industries and industrial
waste-water effluents Location $^{2} \quad \begin{gathered}\text { Municipal, secondary } \\ \text { waste-water effluents }\end{gathered}$

0.6 .0

Columbia Slough

(1.2).

$2.5-12.0$

$3.0-8.0$

3.3
7.0

$7-17$

7.4

Swan Island Channel

(8.1).

11.0

13.7

17.0-27.5

18.4

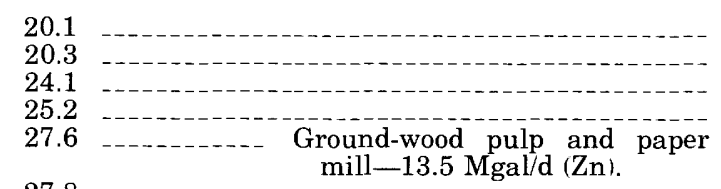

27.8

28.0

28.5

33.0

35.6

48-51

49.2

50.3

54.8

78.2

80.5-87

\section{2}

85.2

107.7
Ground-wood and magnesium sulfite pulp and paper mill- $12.9 \mathrm{Mgal} / \mathrm{d}(\mathrm{Zn})$.

Calcium carbide and related products.

Shipping terminals.

Oil tank farms.

Agricultural organic chemicals

(Cr, $\mathrm{Cu}, \mathrm{Pb}, \mathrm{Ni}, \mathrm{Zn}$ ).

Chlorine and related products

(Cr, $\mathrm{Zn}$ ).

Drydocks and ship repairs.

Cement plant.

Ship salvage yards.

108.0

Fourth Lake (117.0). Metal extraction and processing,

117.9

$118-120$

119.6

$130-134$

130.8

132.0

132.2

147.5

148.0

174-187

174.9

178.6

184.3

187.0
Kraft pulp and paper mill,

resin plant, wood flour mill, oil

tank farm (Zr, Hf, Ta, Nb, V

$\mathrm{W}, \mathrm{Mo}$, and others). ${ }^{4}$

Milwaukie-1.9 Mgal/d (Cr, Ni, and $\mathrm{Zn}$ from plating wastes).

Oak Lodge-1.8 Mgal/d.

Tryon Creek-3.7 Mgal/d.

West Linn-0.7 Mgal/d.

Oregon City-2.8 Mgal/d.

West Linn-0.5 Mgal/d.

Canby-0.3 Mgal/d.

Ground-wood and magnesium sulfite pulp and paper mill11.7 Mgal/d (Zn)

Newberg-0.7 Mgal $/ \mathrm{d}$.

Salem-22 Mgal/d.

Albany-5 Mgal/d.

Corvallis-6 $\mathrm{Mgal} / \mathrm{d}$.

Hardboard mill.

Kraft pulp and paper mill.
Intrusion of Columbia River sediments.

Multnomah Channel.

Combined sewer overflows from Portland $(\mathrm{Pb}$ and others).

Urban storm drainage from Portland metropolitan area ( $\mathrm{Pb}$ and others).
Tualatin River.

Molalla River.

Urban storm drainage from Newberg ( $\mathrm{Pb}$ and others).

Yamhill River.

Urban storm drainage from Salem ( $\mathrm{Pb}$ and cthers).

Boise Cascade Slongh.

Luckiamute River. Santiam River.

Urban storm drainage from Albany ( $\mathrm{Pb}$ and others).

Calapooia River.

Urban storm drainage from Corvallis ( $\mathrm{Pb}$ ard others).

Marys River.

Long Tom River.

Urban storm drainage from Eugene-Sprincfield $\quad(\mathrm{Pb}$ and others):

McKenzie River.

Confluence of Coast Fork and Middle Fork.

'Specific metals associated with specific sources are identified in parentheses by their chemical symbols. (See table 11.$)$ 2River-mile location or river-mile interval unless specifically named.

${ }^{3}$ Approximate flows for summers of 1973 and 1974 .

4See table 14, samples 33-35. 
Fourth Lake, near Albany, is worthy of special mention. The lake, which is actually a slough, receives drainage from 11 industries, including the metal-extraction and processing operations at Teledyne-Wah Chang. Wah Chang extracts zirconium and hafnium from imported ores and produces various alloys from these metals and from tantalum and niobium, which are purchased in purified form (Tom Nelson, Teledyne-Wah Chang, oral and written communs., 1975). The imported ores also contain scandium, yttrium, lanthanum, and ytterbium. Additional metals used in production of alloys include molybdenum, tungsten, tin, chromium, and nickel. At one time, Wah Chang also used silver in the production of a special tungsten alloy.

From the information in table 2 and figure 1, it can be seen that the potential sources of trace metals to the Willamette River are generally known. To determine the effect of these sources on trace-metal occurrence, it was necessary to develop approaches for the collection and preparation of samples.

\section{SAMPLING}

\section{SAMPLING MEDIUM}

Bottom sediments have two major characteristics that make them the best sampling medium for conducting a synoptic basinwide study of trace-metal occurrence. First, fine sediments can usually be found and sampled from most reaches of most large rivers. Second, because trace metals associate strongly with particulate materials, bottom sediments can act as metal accumulators during periods of low velocities when the riverbed is not being scoured. During such periods, the riverbed is a depository for incoming sediments, and these, as well as the sediment already in place, can serve as scavengers of dissolved metals from the passing water. Bottom sediments collected during a stable low-flow condition thus provide the opportunity to obtain information on the presence and distribution of metals over an extended period of time. Such information can be used to delineate areas of anomalously high concentrations and possible sources.

Water, suspended sediment, and aquatic organisms (in contrast to bottom sediment) are less desirable as sampling media for a synoptic trace-metal reconnaissance. In some ways, water is the least desirable because a water sample collected from a flowing river represents the condi- tions that exist at a single instant in time. If the discharge of metal wastes is intermittent (as is often the case), periodic water samples collected downstream may show no pollution. Moreover, even if metal discharge is constant, water samples collected at distant sites may show little or no pollution because the metals could well be adsorbed onto sediment particles during downstream passage.

Suspended sediment can be an ercellent medium for determining trace-metal occurrence during specific runoff events. However, suspended sediment is too transitory to provide a sound sampling basis for synoptic basinwide surveys.

Aquatic organisms, although tre focus of toxicity studies, represent a poor medium for determining the basinwide occurrence of trace metals. The major drawback to this medium is the improbability of finding enough of specific life stages of selected organisms at all predetermined sampling sites.

Therefore, for this study, bottom sediment was selected as the preferred sampling medium.

\section{SAMPLING APPROACH}

Sampling sites were selected to provide (1) general coverage of the entire main stem of the Willamette and (2) specific coverage of locations below possible trace-metal sources (table 2 ). River-velocity data and low-altitude aerial photographs (U.S. Army Corps of Engineers, 1973) were used to determine areas whers fine materials were likely to be found under low-flow conditions.

The objective of field sampling was to obtain sufficient fine-grained material from each site for the laboratory analyses. In the Tidal Reach, satisfactory samples were obtained witr a Petersen dredge by compositing two or three bites at the visual center of flow. At two special sites (see "Sampling from the Visual Center of Flow"), additional samples were collected at predetermined cross-sectional points.

The visual center of flow was used in preference to the center of the cross section because, in many subreaches, the channel and most of the flow is near one bank. At each location, the specific sampling site was determined by combining information provided by aerial photographs (U.S. Army Corps of Engineers, 1973) with information attained by visually estimating the water discharge at various points in the cross sectior. 
In many upstream subreaches, the riverbed is almost completely covered with gravel. In these locations, the sampling approach consisted of searching with an Ekman dredge for small areas of fine-grained sediments. The intent was to determine the relative occurrence of metals in each subreach by using the fine materials in bottom sediments as a natural trace-metal concentrator.

\section{SAMPLING LOCATIONS}

Bottom-sediment samples were collected from 44 sites (figs. 1 and 3) in late September 1973 after a period of more than 4 months of steady low flow. Thirty-one samples were taken from the Willamette River, and 13 from tributaries, sloughs, and other adjacent waters. Site descriptions and gross physical characteristics of the 44 samples are presented in table 9. (Tables 9-15 are presented at the end of this report.)

Geographically, 19 of the sites were associated with the 26.5-mi (42.6 km) Tidal Reach (see fig. 2 and table 1), 7 with the $25.5-\mathrm{mi}(41.0-\mathrm{km})$ Newberg Pool, and 18 with the 135-mi (217-km) Upstream Reach. The sampling density was designed to be greatest in the Tidal Reach because this section of the river is the most highly urbanized and, as previously noted, the subreach between RM's 10 (RK 16) and 3 (RK 5) is the primary depositional area of the Willamette River system.

\section{LABORATORY PROCEDURES AND ANALYTICAL RESULTS}

\section{PHYSICAL PROCEDURES}

The 44 samples were sieved through a plastic 2-mm (millimetre) sieve to exclude the coarse materials. The weight, texture, and visual nature of $>2-\mathrm{mm}$ materials were recorded; the materials varied from sample to sample but included gravel, wood, paper, and snails. (See table 9.) Aliquots of air-dried $<2-\mathrm{mm}$ materials were size fractionated to determine the percentages of sand, silt, and clay and to obtain a $<20-\mu \mathrm{m}$ fraction for analysis of metals. A special air-jet device (Chu and Davidson, 1953) was used to physically disperse the sediments and thereby avoid the metal contamination that would result from use of standard pretreatment chemicals (Jackson, 1956). Particle-size analyses were made by the pipette method (Jackson, 1956) and the fractionations at $20 \mu \mathrm{m}$ by sedimentation and decantation.
The $<20-\mu \mathrm{m}$ materials contain the clay and fine-silt fractions from each whole sample. In grain size, these materials are roughly comparable to claystones and shales, and also to the fine fractions of soils. Fractionation at $20 \mu \mathrm{m}$ therefore provided a basis for comparing the tracemetal results to existing geochemical cata.

\section{ANALYSIS OF METALS}

Fifty elements were investigated using a sixstep semiquantitative emission-spectrographic method developed for geochemical exploration (Myers and others, 1961). Emission spectroscopy determines elements within the structure (crystal lattice) of minerals in addition to those reld at the surface in exchange sites, oxide coatings, and organometallic complexes. Thus, the method yields trace-metal results higher than the concentrations available to aquatic organisms (biologically available) or those determinable by simple acid extraction. The bulk of many trace metals in sediments is associated with iron and manganese hydrous oxides that coat the sediment particles (Jenne, 1968). However, in uncontaminated sediments, 25 percent or more of certain trace metals could be present within crystal lattices.

Because of the inclusion of crystal-lattice metals and the semiquantitative analyses, the emission-spectrographic method was used primarily for the scanning of trace-metal occurrence. The intent of its use was to determine if any of the wide array of investigated motals was present in anomalously high concentrations. Only the $<20$ - $\mu \mathrm{m}$ fractions of samples vere analyzed by this method.

Atomic-absorption spectrophotometry was used to determine more quantitatively the concentrations of cadmium, chromium, copper, lead, mercury, silver, and zinc; colorimetry was used for arsenic. These eight metals were specifically selected for intensive analysis because they are widespread byproducts of man's activities (table 15) and are potentially toxic to aquatic organisms. The wet chemical methods used to determine the metals were developed for geochemical prospecting (Ward and others, 1963 and 1969). These methods are less sensitive than others presently available but are adequate for a reconnaissance. Both whole samples $(<2 \mathrm{~mm})$ and the prepared $<20-\mu \mathrm{m}$ fractions were analyzed for the eight metals. 


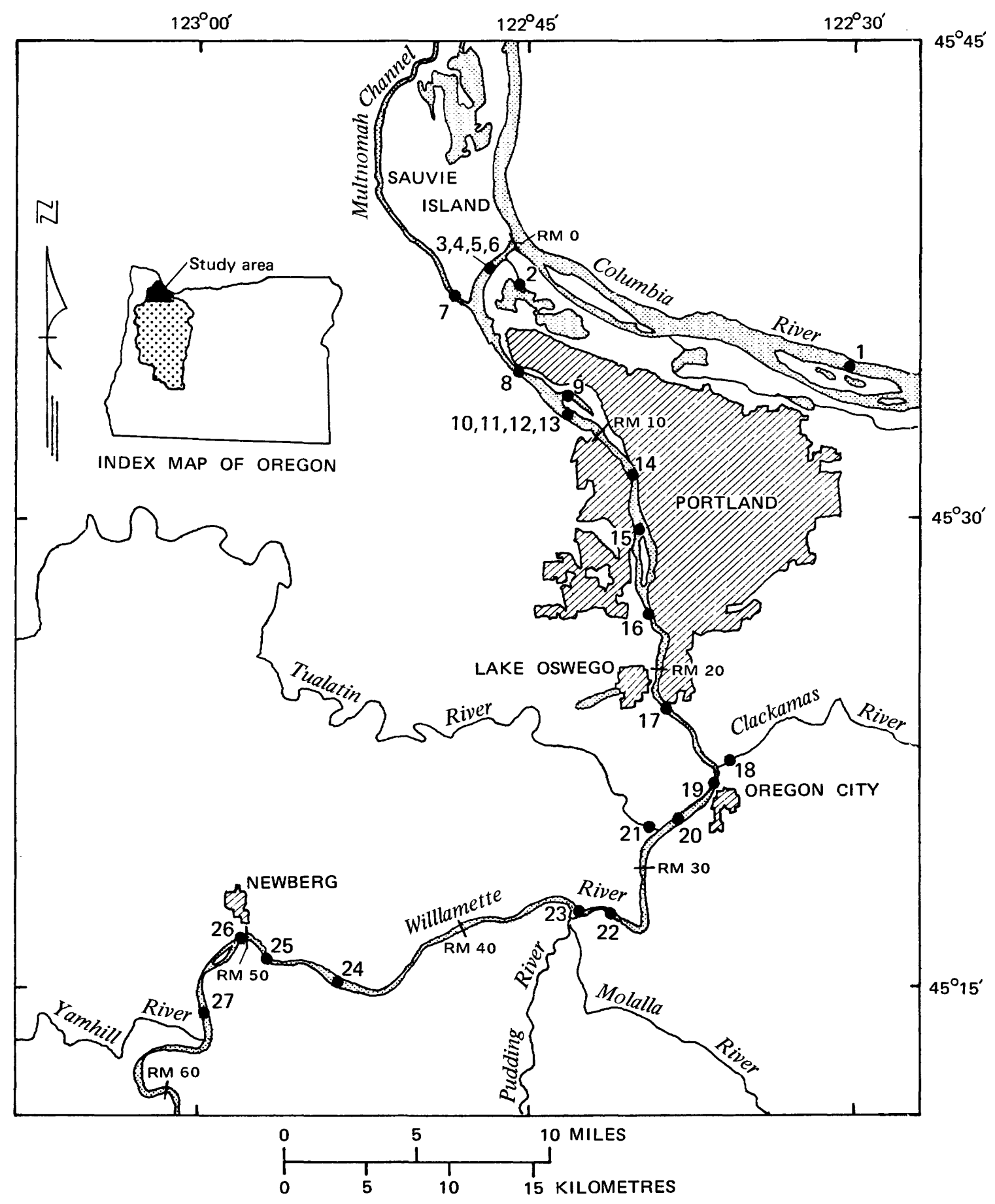

Figure 3.-Sediment-sampling sites in the Tidal Reach and the Newberg Pool.

ANALYTICAL RESULTS

Results obtained by the wet chemical methods are presented in table 3 for both the $<2-\mathrm{mm}$ and $<20-\mu \mathrm{m}$ materials. For easier inspection, the $<20-\mu \mathrm{m}$ results are geographically summarized as averages and ranges in table 4 .

Emission spectroscopy was used to investigate 10 major elements (table 12) and 40 trace ele- 
TABLE 3.-Concentrations of trace metals in bottom sediments from the Willamette River and adjacent wcters ${ }^{1}$ [Concentrations in parts per million?]

\begin{tabular}{|c|c|c|c|c|c|c|c|c|c|c|c|c|c|c|c|c|c|}
\hline \multirow{2}{*}{$\begin{array}{l}\text { Sample } \\
\text { number }\end{array}$} & \multirow[b]{2}{*}{ Site $^{3}$} & \multicolumn{8}{|c|}{$<2$-mm materials ${ }^{4}$} & \multicolumn{8}{|c|}{$<20-\mu \mathrm{m}$ materials } \\
\hline & & As & $\mathrm{Cd}$ & $\mathrm{Cr}$ & $\mathrm{Cu}$ & $\mathrm{Pb}$ & $\mathrm{Hg}$ & $\mathrm{Ag}$ & $\mathrm{Zn}$ & As & $\mathrm{Cd}$ & $\mathrm{Cr}$ & $\mathrm{Cu}$ & $\mathrm{Pb}$ & $\mathrm{Hg}$ & $\mathrm{Ag}$ & $\mathrm{Zn}$ \\
\hline 1 & Columbia River & 10 & 1 & 65 & 5 & 5 & 0.15 & $<0.5$ & 75 & 20 & 4.5 & 60 & 95 & 70 & 0.90 & 1.5 & 460 \\
\hline 2 & Columbia Slough & 10 & 1 & 80 & 10 & 5 & .17 & $<.5$ & 140 & 20 & 2 & 60 & 35 & 35 & .11 & .5 & 270 \\
\hline 3 & 1.5 & 10 & .5 & 85 & 10 & 20 & .10 & $<.5$ & 195 & 10 & 2.5 & 80 & 40 & 40 & .13 & .5 & 340 \\
\hline 4 & 1.5 & $<10$ & .5 & 90 & 10 & 20 & .27 & $<.5$ & 210 & 10 & 2 & 50 & 40 & 40 & .09 & .5 & 350 \\
\hline 5 & 1.5 & $<10$ & .5 & 100 & 15 & 10 & .09 & $<.5$ & 215 & 10 & 1 & 70 & 45 & 40 & .10 & .5 & 340 \\
\hline 6 & 1.5 & 20 & 1 & 90 & 15 & 10 & .08 & $<.5$ & 215 & 20 & 2 & 60 & 40 & 35 & .03 & .5 & 340 \\
\hline 7 & Multnomah Channel & 20 & .5 & 55 & 5 & 5 & .08 & $<.5$ & 150 & 20 & 1.5 & 60 & 35 & 35 & .07 & .5 & 370 \\
\hline 8 & 6.0 & 10 & .5 & 55 & 5 & 10 & .14 & $<.5$ & 145 & 20 & 1 & 60 & 45 & 40 & .14 & .5 & 310 \\
\hline 9 & Swan Island Channel & 20 & 1 & 70 & 25 & 35 & .11 & $<.5$ & 215 & 20 & 1 & 50 & 60 & 35 & .12 & .5 & 315 \\
\hline 10 & 8.5 & 10 & .5 & 80 & 15 & 10 & .11 & $<.5$ & 185 & 10 & 1 & 50 & 40 & 25 & .03 & .5 & 260 \\
\hline 11 & $8.5-10$ & 10 & .5 & 75 & 15 & 30 & .08 & $<.5$ & 225 & 10 & 1 & 50 & 40 & 35 & .03 & .5 & 315 \\
\hline 12 & 8.5 & 10 & $1^{.3}$ & 65 & 10 & 20 & .13 & $<.5$ & 205 & 10 & 1 & 50 & 35 & 40 & .22 & .5 & 335 \\
\hline 13 & 8.5 & 10 & .5 & 70 & 15 & 20 & .20 & $<.5$ & 180 & 10 & .5 & 60 & 40 & 35 & $\therefore 1$ & .5 & 260 \\
\hline 14 & 11.7 & 10 & .5 & 55 & 5 & 5 & .10 & $<.5$ & 155 & 10 & 1 & 50 & 50 & 90 & .34 & 1 & 445 \\
\hline 15 & 13.7 & 10 & 1 & 65 & 10 & 15 & .10 & $<.5$ & 175 & 10 & 1 & 60 & 50 & 40 & .18 & 1 & 395 \\
\hline 16 & $17.0_{0}$ & 10 & .5 & 70 & 10 & 20 & .19 & $<.5$ & 225 & 10 & 1 & 50 & 45 & 25 & .05 & 1 & 470 \\
\hline 17 & 21.1 & 10 & .5 & 60 & 10 & 10 & .16 & $<.5$ & 215 & 20 & .5 & 60 & 55 & 40 & .20 & 1 & 1215 \\
\hline 18 & Clackamas River & 10 & .5 & 90 & 5 & 5 & .07 & $<.5$ & 70 & 10 & 1 & 60 & 30 & 20 & .19 & .5 & 135 \\
\hline 19 & 25.6 & 10 & .5 & 65 & 5 & 10 & .08 & $<.5$ & 180 & 20 & .5 & 50 & 70 & 80 & .16 & .5 & 475 \\
\hline 20 & 27.9 & 10 & .5 & 70 & 5 & 5 & .08 & $<.5$ & 140 & 10 & 1. & 50 & 35 & 20 & .11 & .5 & 295 \\
\hline 21 & Tualatin River & 10 & $1^{.0}$ & 65 & 5 & $1 \stackrel{5}{5}$ & .00 & $<.5$ & $\begin{array}{r}140 \\
85\end{array}$ & 10 & 1.5 & 60 & 40 & 70 & .31 & .5 & 245 \\
\hline 22 & 34.1 & 10 & .5 & 75 & 10 & 10 & .26 & $<.5$ & 155 & 10 & 1 & 50 & 35 & 20 & .26 & .5 & 215 \\
\hline 23 & 34.9 & 10 & .5 & 70 & 5 & 5 & .15 & $<.5$ & 110 & 20 & .5 & 60 & 35 & 20 & .16 & .5 & 210 \\
\hline 24 & 45.8 & 10 & .5 & 65 & 10 & 10 & .13 & $<.5$ & 130 & 10 & .5 & 50 & 35 & 20 & .27 & .5 & 175 \\
\hline 25 & 48.6 & 10 & .5 & 75 & 10 & 10 & .16 & $<.5$ & 120 & 10 & .5 & 50 & 35 & 30 & .24 & 1 & 185 \\
\hline 26 & 50.2 & $<10$ & 1 & 65 & 15 & 20 & .12 & $<.5$ & 130 & 10 & .5 & 50 & 35 & 35 & .05 & 1 & 145 \\
\hline 27 & 54.0 & 10 & .5 & 80 & 15 & 15 & .25 & $<.5$ & 125 & 10 & .5 & 50 & 35 & 30 & .26 & 1 & 140 \\
\hline 28 & 69.0 & 10 & 1 & 70 & 5 & 5 & .14 & $<.5$ & 85 & 10 & .5 & 50 & 35 & 20 & .29 & .5 & 130 \\
\hline 29 & Boise Cascade Slough & 10 & 1 & 65 & 10 & 60 & 14 & $<.5$ & 145 & 10 & 1.0 & 50 & 35 & 80 & .08 & .5 & 165 \\
\hline 30 & 86.7 & 10 & .5 & 60 & 10 & $\begin{array}{r}60 \\
5\end{array}$ & $\begin{array}{l}.14 \\
.08\end{array}$ & $<.5$ & $\begin{array}{r}1+0 \\
80\end{array}$ & $\begin{array}{l}10 \\
10\end{array}$ & .5 & 60 & 40 & 40 & .09 & .5 & 140 \\
\hline 31 & Santiam River & 10 & .5 & 60 & 5 & 5 & 14 & $<.5$ & 80 & 10 & .5 & 40 & 35 & 25 & .05 & .5 & 125 \\
\hline 32 & 112.6 & 10 & .5 & 80 & 5 & 5 & .08 & $<.5$ & 80 & 10 & 1 & 60 & 30 & 10 & .09 & .5 & 135 \\
\hline 33 & Head-Fourth Lake & 40 & 1.5 & 95 & 30 & 65 & .00 & $<.5$ & 190 & 10 & 1 & 80 & 95 & 80 & .12 & 4.5 & 185 \\
\hline 34 & Middle-Fourth Lake & 60 & 1 & 75 & 30 & 100 & .80 & $<.5$ & 185 & 10 & .5 & 80 & 95 & 120 & .09 & 3 & 185 \\
\hline 35 & Fourth Lake near confluence & $<10$ & .5 & 80 & 15 & 15 & .00 & $<.5$ & 110 & 10 & .5 & 50 & 45 & 25 & .02 & 1 & 130 \\
\hline 36 & 1170 & 10 & .5 & 75 & 10 & 5 & .20 & $<.5$ & 110 & 10 & 1 & 50 & 35 & 20 & .38 & .5 & 145 \\
\hline 37 & 1200 & 10 & .5 & 70 & 5 & 10 & .08 & $<.5$ & 90 & 20 & 1 & 50 & 30 & 15 & .31 & .5 & 130 \\
\hline 38 & 130.1 & 10 & .5 & 85 & 10 & 5 & .12 & $<.5$ & 95 & 10 & 1 & 50 & 30 & 15 & .25 & .5 & 115 \\
\hline 39 & Marys River & 10 & .5 & 135 & 10 & 5 & 18 & $<.5$ & 100 & 10 & .5 & 100 & 55 & 15 & .10 & .5 & 130 \\
\hline 40 & 1413 & 10 & .5 & 75 & 5 & 5 & 08 & $<.5$ & 100 & 10 & 1 & 50 & 35 & 35 & .29 & .5 & 160 \\
\hline 41 & 1612 & 10 & .5 & 80 & 5 & 10 & .26 & $<.5$ & 85 & 10 & 1 & 60 & 30 & 45 & .13 & .5 & 175 \\
\hline 42 & 178.1 & 10 & 5 & 65 & 5 & 10 & 04 & $<5$ & 60 & 10 & 1 & 50 & 30 & 25 & 30 & .5 & 145 \\
\hline 43 & 185.3 & 10 & .5 & 65 & $\begin{array}{l}0 \\
5\end{array}$ & 10 & .04 & $<.5$ & 80 & 20 & 1 & 50 & 40 & 70 & .17 & .5 & 120 \\
\hline 44 & Coast Fork & 10 & .5 & 75 & 15 & 35 & .08 & $<.5$ & 140 & 20 & .5 & 50 & 40 & 40 & .10 & .5 & 120 \\
\hline
\end{tabular}

${ }^{1}$ Samples collected September 18-29, 1973. Analyses by Kam W. Leong using atomic-absorption spectrophotometry and colorimetry.

'Concentrations in parts per million (ppm) by weight are equivalent to milligrams of metal per kilogram dry sediment.

3Numbers refer to river-mile locations. Site descriptions are presented in table 9 .

${ }^{3}$ Numbers refer to river-mile locations. Site descriptio
${ }^{4}$ The $<2-\mathrm{mm}$ materials include the $<20-\mu \mathrm{m}$ fraction

ments. Of the latter, 19 were not detected in any of the 44 samples (table 13 ), whereas 21 were detected in at least some of the samples (table 14). The emission-spectrographic data agree with the wet chemical data (table 3 ) and, with the exception of the Fourth Lake and Marys River samples (table 14), indicate the lack of anomalously high concentrations of the less common trace metals. Certain emission-spectrographic data are described in the text, but the following discussions focus primarily on the more quantitative results obtained by the wet chemical methods (table 3 ).

\section{EXAMINATION OF STUDY APPROACHES}

\section{SAMPLING FROM THE VISUAL CENTER OF FLOW}

As previously described, the reconnaissance approach to sampling the Tidal Reach was to collect one sample at each site from the visual center of flow. However, at both RM's 1.5 and 8.5, three additional samples were collected at the crosssectional quarter points. (See table 9.) Data for the $<20-\mu \mathrm{m}$ fractions of these samples are presented in table 5 .

For each location, the concentrations of the eight metals in the visual center-of-flow sample is compared to the range and average of the three quarter-point samples. The largest differences between the averages and the center-of-flow samples were for arsenic, cadmium, chromium, and mercury at RM 1.5 and for lead, mercury, and zinc at RM 8.5. However, if each of these relative differences is examined in relation to sample-tosample variation among the 44 samples (table 3 ), the only values that seem anomalous are for mercury at RM 8.5 and possibly for chromium at RM 1.5. Mercury concentrations were the most variable of the eight metals (table 3); therofore, the wide variation in mercury levels at $R M \quad 8.5$ are consistent with basinwide results. 
TABLE 4.-Geographic distribution of trace-metal concentrations (parts per million) in the $<20$ - $\mu$ m materials of bottom sediments from the Willamette River and adjacent waters ${ }^{1}$

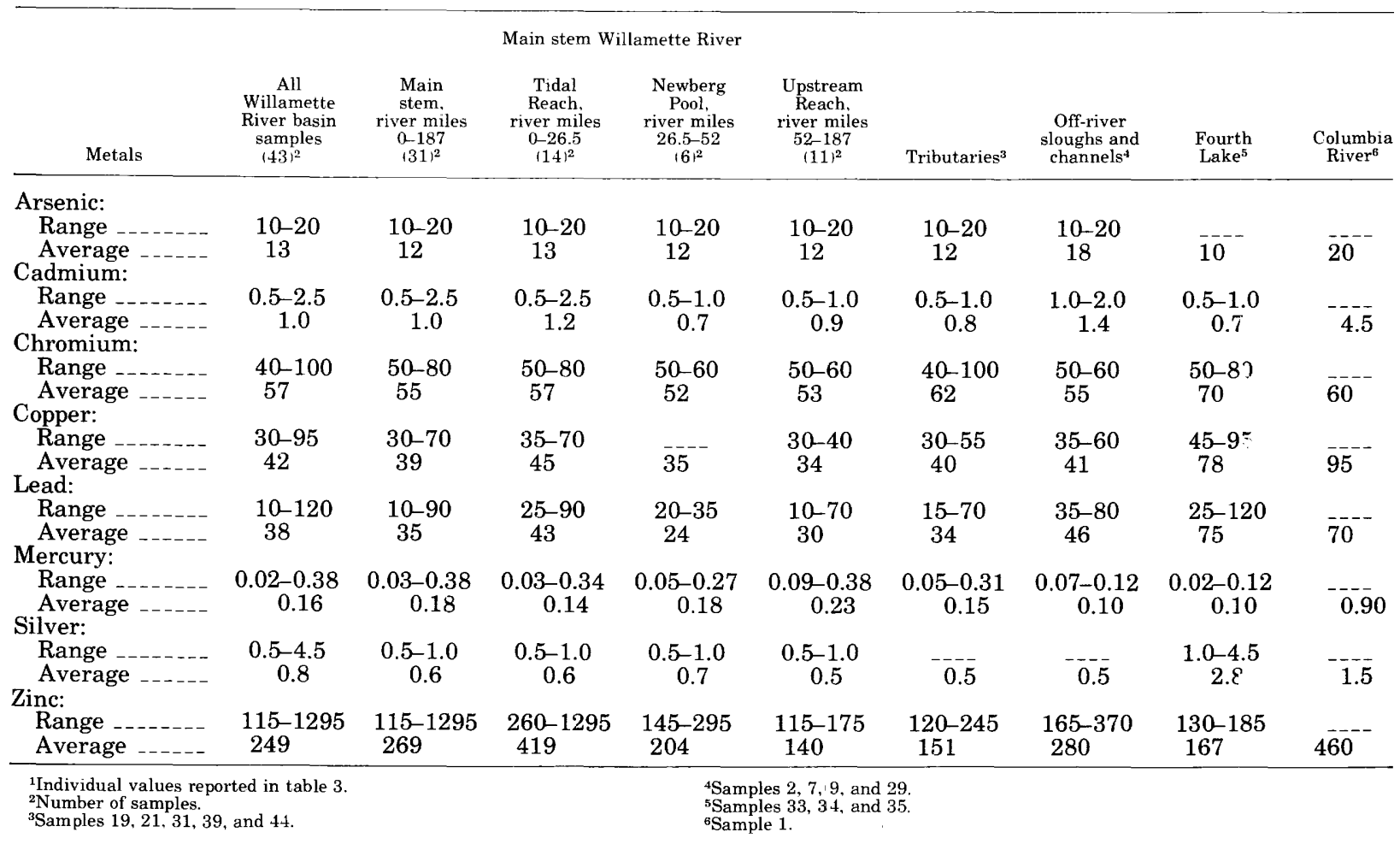

TABLE 5.-Comparison of trace-metal concentrations (parts per million) in center-of-flow samples to cross-sectional samples for the $<20$ - $\mu \mathrm{m}$ materials ${ }^{1}$

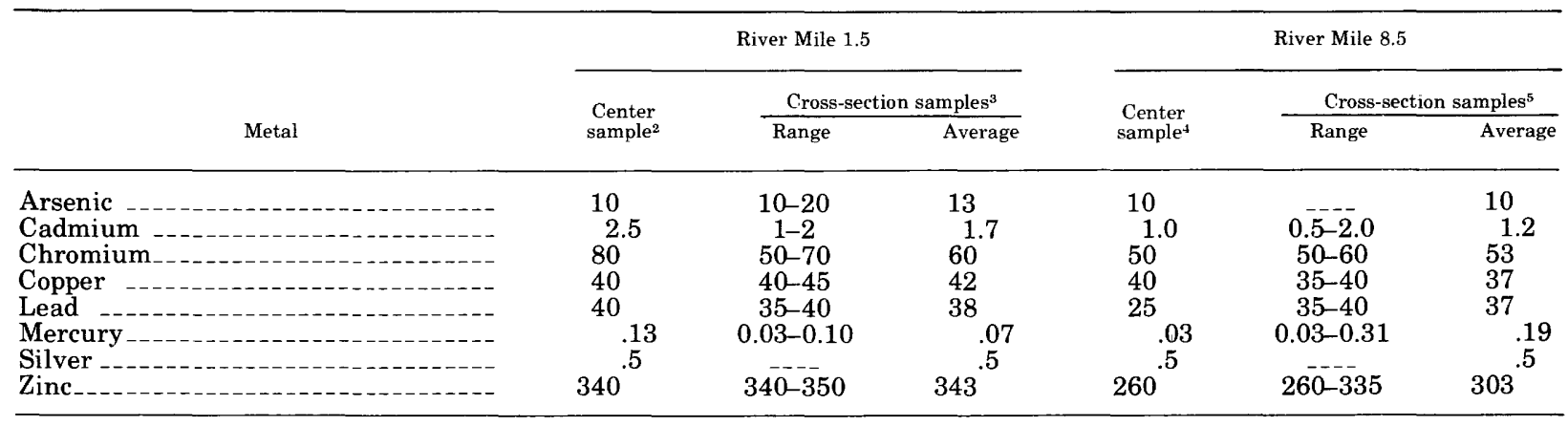

${ }^{1}$ For specific locations and physical data, see tables 9 and 10. Trace-metal data are compiled from table 3 .

Sample 3.

Samples 4-6.

Samples 11-13.

Although based on limited data, the comparisons in table 5 suggest that the sampling approach for the Tidal Reach (one composite sample from the visual center of flow) provided a reasonable basis for describing trace-metal distributions. A similar examination of data from RM's 8.5 and 1.5 was made using the $<2-\mathrm{mm}$ results. For most metals, the concentrations showed a greater degree of cross-sectional variability than was observed in the $<20-\mu \mathrm{m}$ materials. This greater variability was consistent with measured cross-sectional differences in particle-size composition. (See table 10.)

FRACTIONATION OF SAMPLES AT $20 \mu \mathrm{m}$

One reason for obtaining $<20-\mu \mathrm{m}$ fractions was 
to minimize variations in metal concentrations that normally arise from sample-to-sample differences in the proportion of fine-grained materials. (See above.) This section examines whether or not this objective was achieved.

Table 3 provides a general comparison of metal concentrations in the $<20-\mu \mathrm{m}$ materials (clay plus fine silt) with those in the $<2$-mm materials (combined clay, silt, and sand-sized fractions). The concentrations of chromium, copper, lead, mercury, and zinc are sufficiently above the respective analytical detection limits to permit further comparisons through the computation of ratios. Using all 44 samples, the ratios of the average concentrations in $<20-\mu \mathrm{m}$ to $<2-\mathrm{mm}$ materials are copper 4.3 , lead 2.4 , zinc 1.8 , mercury 1.2 , and chromium 0.8 . These ratios suggest that sample-to-sample variations in the proportion of $<20-\mu \mathrm{m}$ materials could largely determine the measured concentrations of copper, lead, and zinc (ratios appreciably different from 1.0), while having little effect on mercury and chromium (ratios close to 1.0 ).

To investigate this hypothesis, scatter plots (fig. 4) were prepared to show the metal concentrations in the $<2$-mm samples as a function of the weight percentage of $<20-\mu \mathrm{m}$ materials in each sample (table 10 , column 6 ). As anticipated, the copper, lead, and zinc concentrations show tendencies to increase with increasing percentages of $<20-\mu \mathrm{m}$ materials. The scatter of data suggests that the relationship is most definite for copper and somewhat less for lead and zinc. In contrast, similar plots (not shown) for both chromium and mercury showed a random scatter of points. The combined results indicate that sample surface area, as represented by the weight percentage of $<20-\mu \mathrm{m}$ materials, was an important control on the measured concentrations of copper, lead, and zinc but an insignificant control on the occurrence of chromium and mercury.

As further verification, a second set of scatter plots was prepared to relate the concentrations of copper, lead, and zinc in each $<20-\mu \mathrm{m}$ fraction to the weight percentage of $<20-\mu \mathrm{m}$ materials in each $<2-\mathrm{mm}$ sample. As expected, the plots (not shown) showed a scatter of the 44 points and hence no correlations such as observed for the $<2$-mm plots (fig. 4). This indicates that the approach of using $<20-\mu \mathrm{m}$ fractions successfully standardized the variations in metal concentrations that otherwise would have resulted from sample-to-sample differences in the percentages of fine-grained materials. This means that the
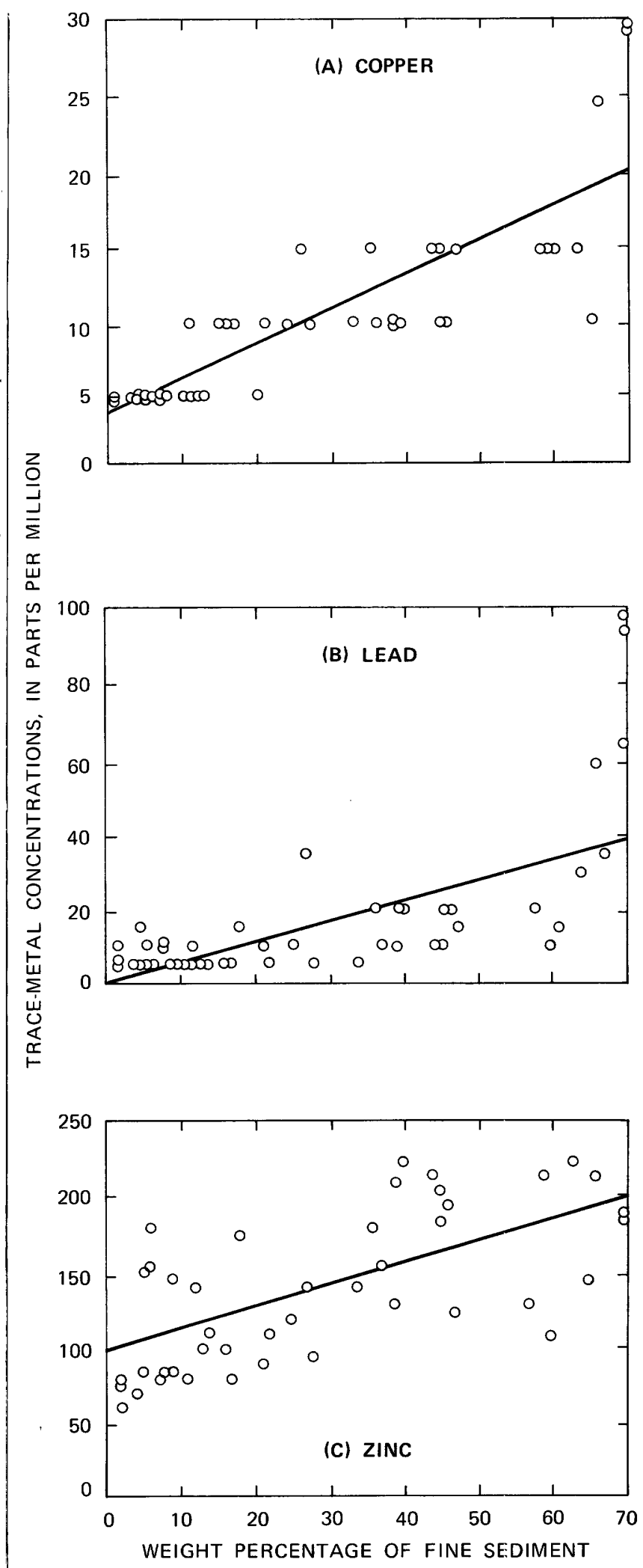

FIGURE 4.- Relation of trace-metal concentrations in $<2-\mathrm{mm}$ materials to the percentage by weight of $<20-\mu \mathrm{r}$ materials. A, copper, $\mathrm{B}$, lead, and $\mathrm{C}$, zinc. 
$<20-\mu \mathrm{m}$ data can provide a sound comparative basis for detecting trace-metal pollution.

In addition to investigating the effect of particle size, a brief assessment was made of the relationship between selected metals and organic carbon. Scatter diagrams indicated that copper and lead concentrations had some tendency to increase with increasing contents of organic carbon. In contrast, the levels of zinc, mercury, and chromium were not related to organic carbon content.

\section{DISTINGTION BETWEEN NATURAL BACKGROUND AND POLLUTION}

If trace metals in Willamette River sediments represented only natural or unpolluted conditions, the concentrations might be expected to follow either a normal or a log-normal distribution (Levinson, 1974). Furthermore, because the fine bottom sediments are derived primarily from the weathering of two chemically related rock types (andesite and basalt), the natural concentrations of the metals might be expected to be distributed as one statistical population.

To test these assumptions for the purpose of distinguishing polluted from unpolluted conditions, the concentrations of chromium, copper, lead, mercury, and zinc in the $<20-\mu \mathrm{m}$ materials were plotted on probability papers according to the method described by Velz (1970, p. 522-542). Plots were not prepared for arsenic, cadmium, nor silver because the determined concentrations were uniformly low. (See table 3.) In preparing the plots, the Columbia River sample was excluded, providing a total of 43 data points (concentrations) for each metal.

Examination of completed plots showed that the metal concentrations more closely conformed to a normal rather than a log-normal distribution. Normal-probability plots were thus used as the basis of the interpretive approach.

\section{ZINC}

The normal-probability plot of zinc concentrations ( $<20 \mu \mathrm{m}$ materials) defines a two-stage curve with a sharp break at $145 \mathrm{ppm}$ (parts per million) (fig. 5A). The lower segment of the curve represents 15 samples, and the upper segment 27 samples; the concentration of $1,215 \mathrm{ppm}$ from RM 21.1 (table 3) stands by itself far off the upper end of the scale.

From foreknowledge of the potential sources of zinc pollution (see table 2), it was expected that samples collected downstream from the pulpmill at RM 49.2 would show higher concentrations than those taken from farther upstrear. This is confirmed by figure $5 \mathrm{~A}$, because the $1 \mathrm{~F}$ samples represented by the lower segment were collected above RM 50. The concentrations of these samples were replotted in figure $5 \mathrm{~B}$, and a welldefined normal distribution was formed, as evidenced by the straight-line fit.

Spatially, the increased levels of zinc in the Newberg Pool and the Tidal Reach corresponded to the locations of the three ground-wood pulpmills (compare tables 2 and 3). The especially high concentrations between RM's 25.6 to 11.7 were below the outfalls of the two mills located between RM's 27 to 28 .

The combined knowledge of zinc sources and concentrations indicates that the lower segment in figure $5 \mathrm{~A}$ represents natural background conditions, whereas the upper segment represents polluted conditions. The spatial distribution of concentrations precludes the possibility that the two-stage curve results from areal differences in geochemistry.

\section{LEAD}

Lead concentrations (in $<20-\mu \mathrm{m}$ materials), like those of zinc, define a two-stage curve when plotted on normal-probability paper (fig. 6A). The lower curve includes concentrations from 10 to 40 $\mathrm{ppm}$ and the upper curve concentratiors from 45 to $120 \mathrm{ppm}$. As with zinc, the levels on the upper segment seem to represent pollution.

In contrast to zinc, the enriched lead concentrations occurred at discrete locations (seo table 3 ) rather than in a large downriver zone. Most of the lead-enriched sites were in urban areas. suggesting that the pollution resulted largely from storm drainage from streets and roads. (See table 2.) The high-concentration site at RM 1.85 .3 was within the storm-drainage zone of the EugeneSpringfield area, and the sample at RM 161.2 was collected near the highway bridge at Harrisburg. In the Tidal Reach, the samples at both RM's 25.6 and 11.7 were collected just below bridges which cross the Willamette.

Other lead-enriched samples were collected from Fourth Lake, Boise Cascade Slough, and the Tualatin River. Boise Cascade Slough receives garbage-dump leachate which may account for the elevated lead concentration. Alsc the elevated lead content of the Tualatin River sample is consistent with the high degree of urban development in the basin. 


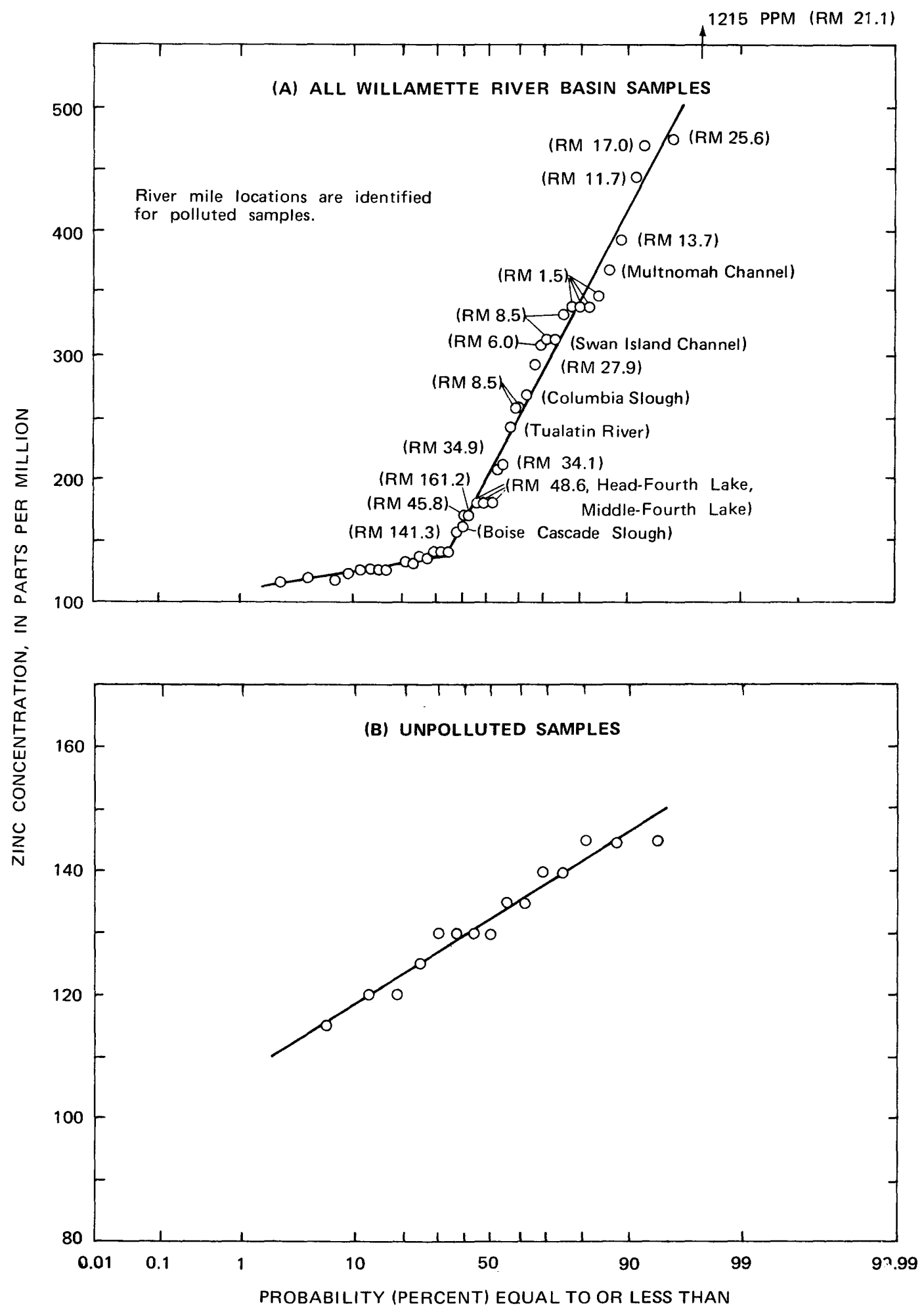

FIGURE 5.-Normal-probability plots of zinc concentrations in $<20-\mu \mathrm{m}$ materials. A, All Willamette Rivor basin samples. B, Unpolluted samples.

Comparison of data in table 3 with possible pol- $\mid$ receive either urban runoff or storm drainage lution sources shown in table 2 indicates that all lead concentrations $>25 \mathrm{ppm}$ are from sites that suggests that lead concentrations from 10 to 40 


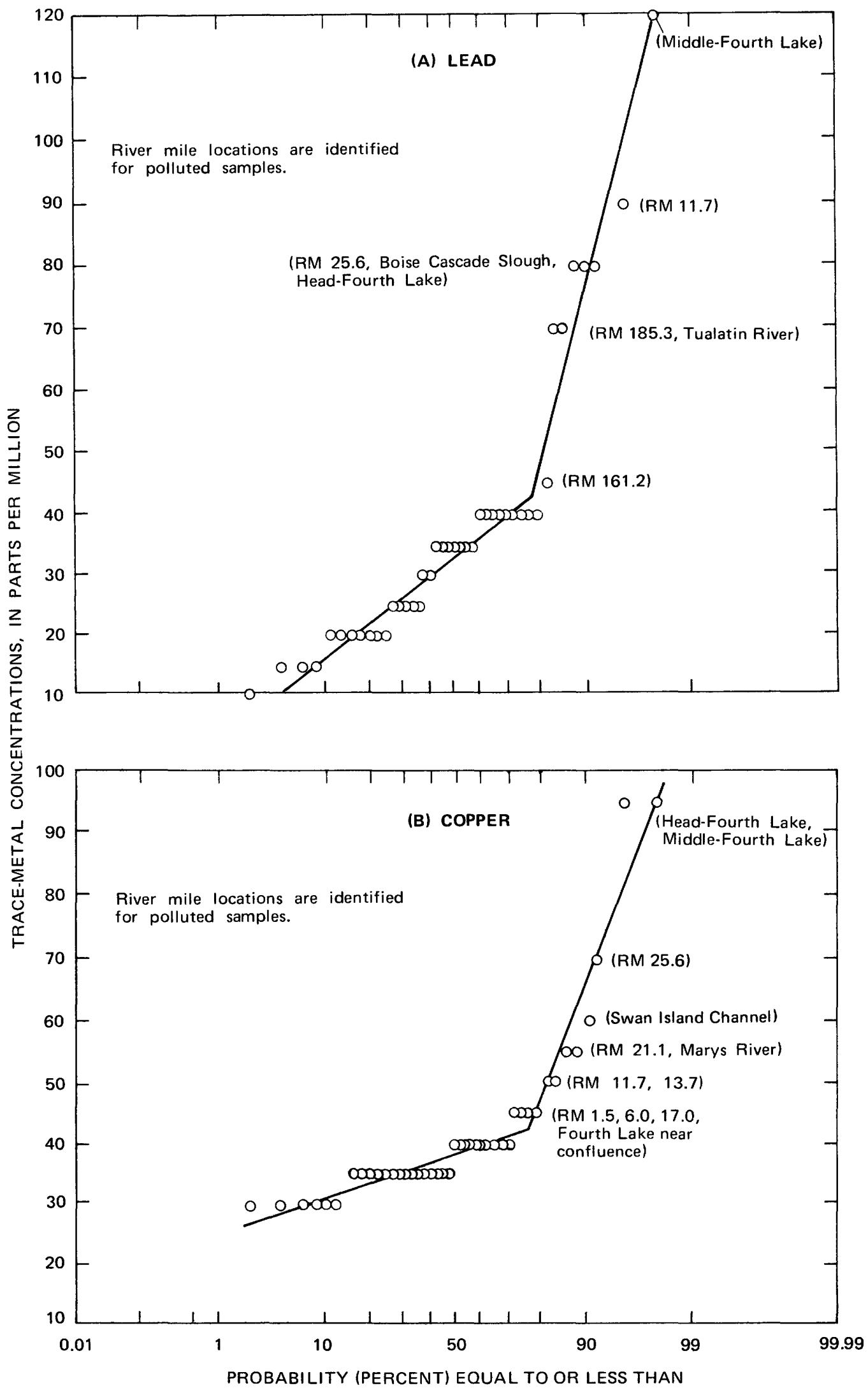

FIGURE 6.-Normal-probability plots of trace-metal concentrations in $<20-\mu \mathrm{m}$ materials. A, lead, and B, copper. 
ppm are from one population, the comparison suggests that concentrations $>25$ ppm might constitute pollution. Moreover, as described in a following section (see "Comparison of Results to Trace-Metal Concentrations in Rocks and Soils"), such a delineation is more consistent with lead concentrations in Willamette River basin soils.

Geographically, if we use the 25-ppm value as a breakpoint, zones of lead enrichment occur around Newberg (samples 25 to 27) and in the Tidal Reach (all Tidal Reach samples except RM 17.0 ). As noted in table 2 , the Willamette receives street runoff below RM 27.5, either in the form of urban storm drainage or combined sewer overflows. Samples 25 and 26 from near Newberg were collected in a subreach that receives urban runoff. In addition to the two zones, lead enrichment would also be designated at RM 86.7 (sample 30 ), which is adjacent to a highway, and at RM 141.3 (sample 40), which is just below the village of Peoria.

Further discussion of the threshold concentration for lead enrichment is presented in "Comparison of Results to Trace-Metal Concentrations in Rocks and Soils.”

\section{COPPER}

The plot of copper concentrations on normalprobability paper is best fitted by a two-stage curve (fig. 6B). The geographic locations (identified in fig. $6 \mathrm{~B}$ ) of samples on the upper curve are suggestive of pollution. The locations include Fourth Lake ( 3 samples), the Marys River, a zone between RM's 11.7 and 25.6 (samples 14, 15, 16, 17 , and 19 in table 3 ), and Swan Island Channel plus the immediate downstream site (RM 6.0). The Marys River sample also contained relatively high concentrations of cobalt, nickel, and vanadium (table 14), as well as chromium. (See "Chromium".) The high copper concentrations between RM's 11.7 and 25.6 coincide with the zone of high zinc concentrations (fig. 5) and with elevated levels of lead. The cause of the elevated copper concentrations in this zone is unknown, but possible sources include municipal secondary effluents (table 2 ) in addition to the urban drainage and the pulp and paper mill effluents.

\section{CHROMIUM}

Chromium concentrations also define a twostage curve on normal-probability paper (fig. 7A).
Two of the three 80-ppm samples were from Fourth Lake, and the 100-ppm sample was taken from the Marys River. As previously noted, the Marys River sample also contained relatively high levels of cobalt, copper, nickel, and vanadium. There is no known cause for the elevated levels of these metals.

In addition, enriched concentrations of 70 and $80 \mathrm{ppm}$ were determined in two of the samples from RM 1.5.

\section{MERCURY}

Mercury concentrations (fig. 7B) tend toward one normally distributed population. but there are erratic variations above and below a good straight-line fit. Examination of geographical distributions (table 4) indicates that average mercury concentrations in the $<20-\mu \mathrm{m}$ materials increased slightly in an upriver direction. It was initially considered that the increase might have resulted from enrichment by the old Plack Butte mining area (fig. 1). However, the one sample (number 44) collected below Black Butte on the Coast Fork Willamette had low mercury concentrations in both the $<2-\mathrm{mm}$ and $<20-\mu \mathrm{m}$ samples (table 3). Resolution of whether the Flack Butte area is polluting the Willamette roust await further study.

Mercury was once used for slime cortrol by certain pulp and paper mills in the basir. However, this use was discontinued in the late 1960's (A. Caron, Regional Director, Natioral Council for Stream and Air Improvement, personal commun., 1975).

Although none of the $<20-\mu \mathrm{m}$ fractions showed definite mercury pollution, the $<2$-nom sample from site 34 (Fourth Lake) was unquestionably enriched $(0.80 \mathrm{ppm})$. The mercury was associated with the coarse solids of the sample, but the source is unknown. Because the sediments sampled from Fourth Lake may have accumulated over many years, it is also unknown whether the pollution resulted from waste discharges during 1973 or from a previous time.

In summary, based on the lack of a two-stage probability plot and the lack of proven sources, we conclude that mercury concentrations in the $<20-\mu \mathrm{m}$ materials are probably representative of unpolluted conditions. The relatively poor fit of the concentrations to a straight line (in fig. 7B) suggests some possible pollution, but if it exists, it is apparently not very great. 


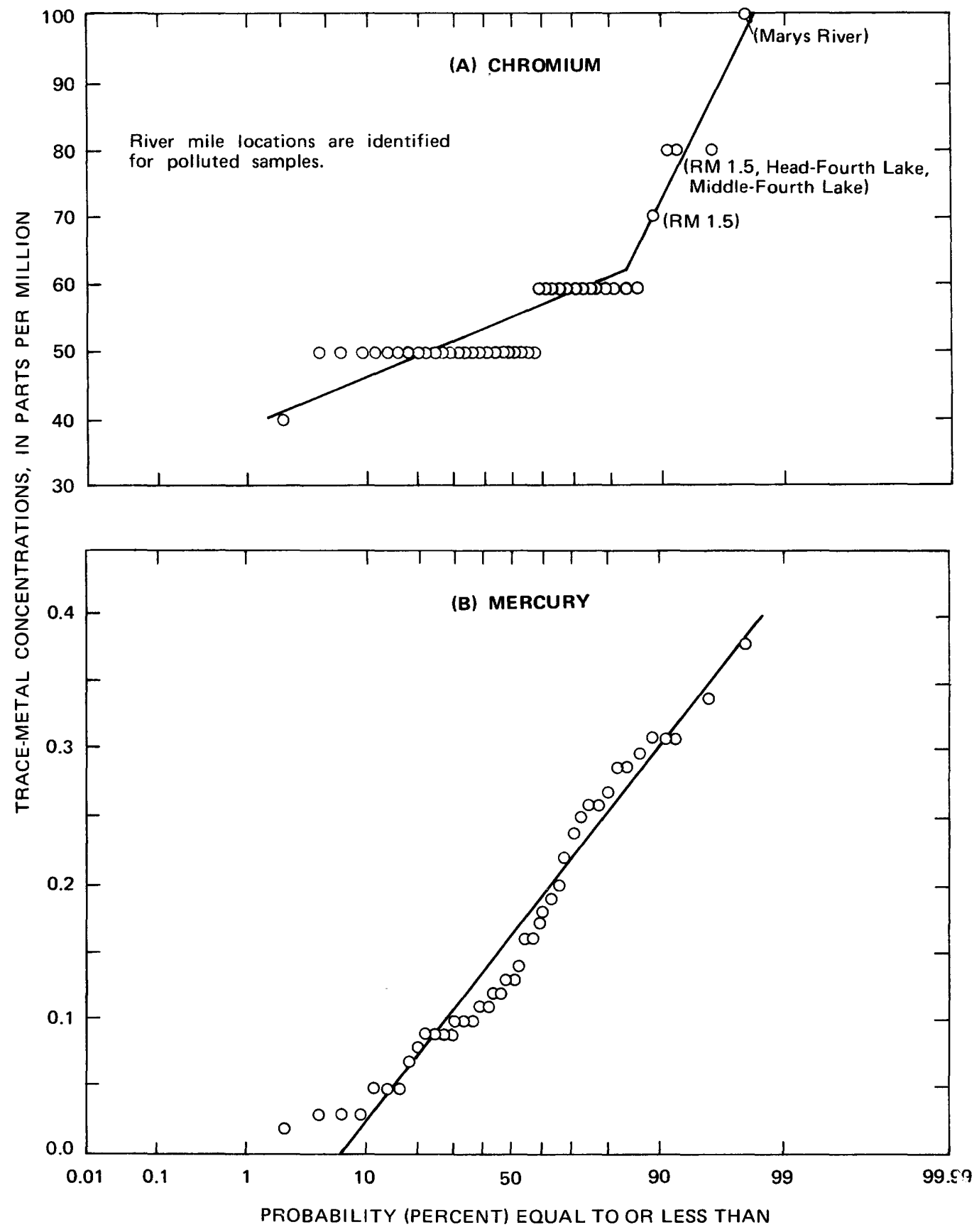

Figure 7.-Normal-probability plots of trace-metal concentrations in $<20-\mu \mathrm{m}$ materials. A, Chromium, and B, Mercury.

\section{CADMIUM}

Cadmium concentrations did not show enough variability to warrant plotting. However, there was a slight increase in cadmium concentrations $(<20-\mu \mathrm{m}$ materials $)$ in the lower $3 \mathrm{mi}(5 \mathrm{~km})$ of the river (table 3). Upstream from this point, cadmium concentrations were reported as either
0.5 or $1.0 \mathrm{ppm}$ in all but one sample (Tualatin River). In contrast, in Multnomah Channel (RM 3.3) the cadmium concentration was $1.5 \mathrm{ppm}$, at RM 1.5 it averaged 1.9 (four samples), and in the Columbia Slough it was $2.0 \mathrm{ppm}$.

One possible cause of the increase is admixture of Columbia River sediments which might move 
upstream into the Willamette during periods of flow reversal. (See "Willamette River Morphology.") The one sample analyzed from the Columbia had a cadmium content of $4.5 \mathrm{ppm}$ in the $<20$ - $\mu$ m materials. However, the Columbia River sample also had elevated contents of copper, lead, and mercury, and no corresponding enrichment of these metals was detected in the lower Willamette.

\section{FOURTH LAKE}

The sediments from sites 33 and 34 in Fourth Lake were black, oily, odorous (table 9), and composed entirely of clay and silt-sized materials (table 10). In contrast, sample 35 , collected near the confluence of Fourth Lake with the Willamette, showed indications of mixing with coarse river sediments. In reporting the trace-metal data (table 6), the concentrations at sites 33 and 34 are averaged, and the values at site 35 listed separately. For comparison, table 6 also lists the average and modal concentrations of each metal in the other Willamette River basin samples.

Table 6 indicates that the Fourth Lake samples were polluted by a large number of metals. Of the total list of enriched metals, the following 11 can be associated with processes at Teledyne-Wah Chang (see section entitled "Possible Sources of Trace Metals"): chromium, hafnium, lanthanum, molybdenum, niobium, scandium, silver, tin, ytterbium, yttrium, and zirconium.
Arsenic, copper, lead, and mercury were also enriched, but the sources of these metals are unknown. The arsenic and mercury enrichments occurred only in the $<2-\mathrm{mm}$ samples.

Although Fourth Lake was heavily polluted, the sample collected just downstrsam at RM 112.6 (table 3 ) showed no enrichment of any of the noted metals. Moreover, none of the special metals discharged by Teledyne-Wah Chang was determined at enriched levels in any downstream sample. Thus, it seems that metals discharged into Fourth Lake precipitate and stay within the slough, at least under low-flow conditions. If the metals do flush from the slough at high flows, they must (1) flush entirely from the basin, (2) be diluted to background levels, (3) be annually buried at depths greater than those sampled in the study (improbable), or (4) be afferted by some combination of these possibilities. Further work is needed to determine if Fourth Lake is actually a year-round sink of incoming metals and, if so, whether the capacity for storage is still very large or possibly nearing its limit.

\section{COMPARISON OF RESULT $\mathrm{N}_{\mathfrak{N}}$ TO TRACE-METAL CONCENTRATIONS IN ROCKS AND SOILS}

The approach of using normal-prok ability plots (figs. 5, 6, 7) provides a means for estimating the natural background concentrations of certain

TABLE 6.-Concentrations (parts per million) of trace metals in Fourth Lake

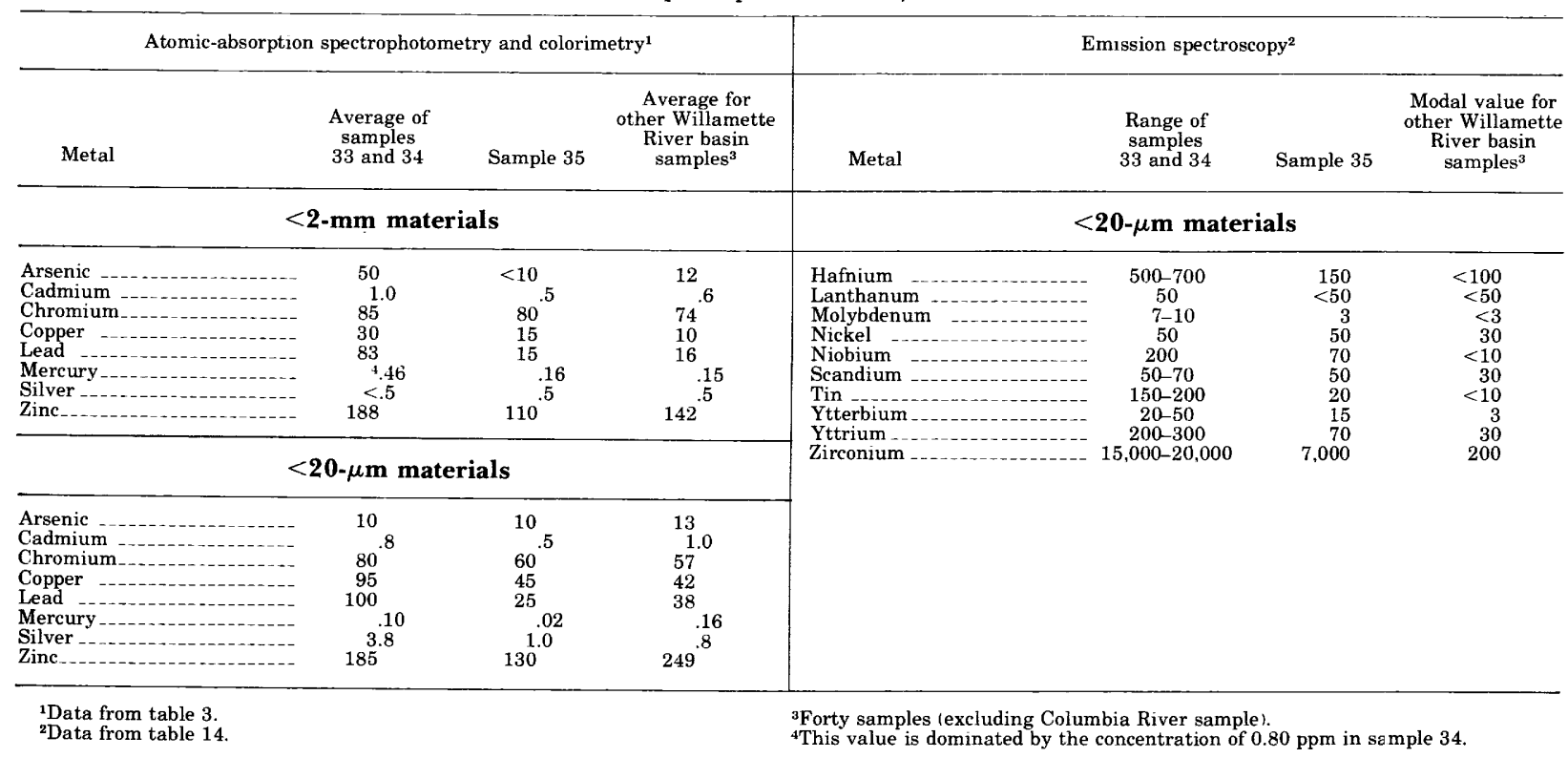


trace metals in Willamette River sediments. Figure $5 \mathrm{~B}$ shows the distribution of zinc concentrations in the 15 samples designated as unpolluted. The figure shows that a well-defined normal distribution is formed, which, by graphical analysis (see Velz, 1970, p. 522-542), yields a mean of 133 ppm and a standard deviation of $12 \mathrm{ppm}$. Similar plots were prepared (not shown) for the graphically defined natural background concentrations of lead, copper, and chromium $(<20-\mu \mathrm{m}$ materials). The summary data for the four metals are presented in table 7 .

Because no definite breakpoint occurs in the mercury plot (fig. 7B), the data are considered as representing unpolluted conditions. The mean of the 43 concentrations is $0.17 \mathrm{ppm}$, and the standard deviation is $0.11 \mathrm{ppm}$.

Column 2 of table 8 shows the mean of the mercury samples together with the means (from table 7) of the unpolluted samples of chromium, copper, lead, and zinc. These values represent our initial estimates of the natural background concentrations of the five metals in the $<20-\mu$ m materials.

Table 8 compares these estimated background concentrations to levels for the five metals in rocks and soils of the Willamette Basin and to worldwide averages in claystones and shales. The values shown for Willamette Basin rocks represent uncontaminated consolidated specimens, most of which were basaltic or andesitic in character. The soils data represent "natural" conditions (Shacklette and others, 1971) and were determined on fractionated materials roughly comparable in size to the $<20-\mu \mathrm{m}$ materials of the present study. The data for claystones and shales represent worldwide averages for uncontaminated samples and were calculated from the values reported by Parker (1967). Claystones and shales are fine-grained rocks which have formed primarily from consolidation of the sediments carried by ancient rivers. Thus, the chemical composition of these rock types would be expected to resemble that of the finer sediments transported by unpolluted present-day rivers.

Average concentrations for the soils are in remarkable agreement with the mean values for claystones and shales. In comparison to these two sets of values, the concentrations from the Willamette Study are low for chromium, copper, and mercury and somewhat high for lead and zinc. However, as previously discussed (see "Lead"),
TABLE 7.-Summary data from normal probability plots of trace-metal concentrations $(<20-\mu m$ materixls $)$

\begin{tabular}{|c|c|c|c|c|}
\hline \multirow[b]{2}{*}{$\begin{array}{l}\text { Trace } \\
\text { metal }\end{array}$} & \multirow[b]{2}{*}{$\begin{array}{l}\text { Breakpoint } \\
\text { concentration } \\
\text { 'ppm! }\end{array}$} & \multicolumn{3}{|c|}{$\begin{array}{l}\text { Summary data for concentrations } \\
\text { below the breakpoint (indicative of } \\
\text { unpolluted or natural background } \\
\text { conditions) }\end{array}$} \\
\hline & & $\begin{array}{l}\text { Number } \\
\text { of samples }\end{array}$ & $\begin{array}{l}\text { Mean } \\
\text { (ppm) }\end{array}$ & $\begin{array}{l}\text { Standard } \\
\text { deviation } \\
\text { (ppm) }\end{array}$ \\
\hline Chromium $_{\ldots}$ & 60 & 38 & 53 & 6 \\
\hline Copper & 43 & 31 & 35 & 9 \\
\hline Lead _. & 43 & 35 & 30 & 10 \\
\hline Zinc & 145 & 15 & 133 & 12 \\
\hline
\end{tabular}

TABLE 8.-Trace-metal concentrations (in parts per million) in bottom sediments, rocks, and soils

\begin{tabular}{|c|c|c|c|c|}
\hline \multirow[b]{3}{*}{ Metal } & \multicolumn{4}{|c|}{ Source } \\
\hline & $\begin{array}{l}\text { Willamette } \\
\text { Study }{ }^{1}\end{array}$ & Willa & tte & \multirow[b]{2}{*}{$\begin{array}{c}\text { Claystones } \\
\text { and } \\
\text { shales }\end{array}$} \\
\hline & $\begin{array}{l}<20-\mu \mathrm{m} \\
\text { materials }\end{array}$ & Rocks $^{2}$ & Soils ${ }^{3}$ & \\
\hline Chromium & 53 & $<1-500$ & 70 & 95 \\
\hline Copper & 35 & $\begin{array}{r}5-300 \\
(30)\end{array}$ & 50 & 51 \\
\hline Lead & 30 & $\begin{array}{r}<10-15 \\
(<10)\end{array}$ & 15 & 20 \\
\hline $\begin{array}{l}\text { Mercury } \\
\text { Zinc }-1 .\end{array}$ & $133^{.17}$ & $\begin{array}{r}<25-159 \\
(<25)\end{array}$ & $68^{.2}$ & $88^{.4}$ \\
\hline
\end{tabular}

${ }^{1}$ Average concentrations for "unpolluted" samples (table 71. See text for discussion of lead in "unpolluted" samples.

of lead in unpolluted samples. throughout the Willamette River basin (R. Mendes, U.S. Geol. Survey, written throughout the

commun., 1975 ) ${ }^{3}$ Values for chromium, copper, and lead represent modal concentrations of 50 soils;
values for mercury and zine represent the average concentration of 3 soils $(R$. Mendes, written commun., 1975; T. H. Shacklette, U.S. Geol. Survey, written commun., 1975 ।.

${ }^{4}$ Values represent averages from Parker (1967, table 19).

the upper end of the range for unpolluted lead concentrations may be $25 \mathrm{ppm}$. On the basis of this breakpoint, the average concentration of the unenriched lead samples is $20 \mathrm{ppm}$. This value is consistent with the data for soils and claystonesshales. It therefore supports the selection of 25 ppm as the breakpoint concentration.

The average zinc concentration in table 8 for Willamette sediments is considerably greater than the averages for soils and for the claystones and shales. We previously noted that old mining areas represent possible sources of zinc pollution in the upper Willamette (see "Possible Sources of Trace-Metal Pollution"); however, examination of table 3 indicates that above RM 50 zinc concentrations varied randomly and were unaffected by the discharge of tributaries (fig. 1) which drain the mineralized areas. We therefore believe that the average zinc concentration of 133 ppm $(<20-\mu \mathrm{m}$ materials) represents the natural background level for Willamette River sədiments. 


\section{SUMMARY AND CONGLUSIONS}

This study developed and applied a procedure for identifying trace metals in river-bottom sediments that are present in concentrations indicative of pollution. The procedure involves (1) physical separation of materials $<20 \mu \mathrm{m}$ in size from bulk sediment samples, (2) trace-metal analysis of the $<20 \mu \mathrm{m}$ materials, (3) examination of the determined metal concentrations through use of probability plots, and (4) comparisons of the concentrations with the metal contents of soils and rocks. The procedure could be used intact or in modified form for the study of other rivers.

Use of the procedure in the Willamette River basin revealed a clean environment with the exception of a moderate enrichment of zinc, slight enrichment of copper and lead, and pollution by several metals in Fourth Lake.

The zinc enrichment resulted primarily from use of zinc hydrosulfite as a brightening agent in three ground-wood pulp and paper mills. As a result of orders from the Oregon Department of Environmental Quality, the mills will cease using zinc hydrosulfite by July 1977 . The lead enrichment appeared to be related directly to urban drainage, but no specific source was identified for copper. Fourth Lake, an industrial slough, showed enrichment of 15 elements including uncommon metals such as zirconium, hafnium, yttrium, ytterbium, and tin. However, none of these metals was present in enriched concentrations at any downstream site.

The study results suggest that no metals were accumulated in Willamette River sediments at concentrations which might represent an immediate ecological threat. However, from a resource management standpoint, further studies are needed to determine (1) how zinc concentrations in the Tidal Reach respond to the ban on zinc hydrosulfite, (2) how much lead is annually reaching the river from urban drainage and combined sewer overflows, and (3) the ultimate fate of metals discharged to Fourth Lake. Answers to these questions still will not define the relationship of trace-metal concentrations in Willamette sediments to possible long-range potentials for toxic effects. It is hoped that basic knowledge of aquatic ecosystems will advance rapidly in the near future so studies can be initiated in the Willamette and in other United States rivers to assess this critical relationship.

\section{ACKNOWLEDGMENTS}

We wish to acknowledge the aid and encouragement of the Non-Federal Advisory Committee on Water Data for Public Use. Our special thanks go to the members of the Advisory Committee's Ad Hoc Working Group on River Quality Assessment. During the Willamette Study, the group included Howard B. Brown, Robert A. Canham, Edward J. Cleary, Laurence R. Jahn, John E. Kinney, Walter A. Lyon, John A. Roller, and Clarence J. Velz. The report could not have been prepared without the careful chemical analyses provided by Kam W. Leong and the spectrographic analyses by Raymond G. Harens. The authors also acknowledge the aid of Warren C. Westgarth during the design ard fieldwork phases of the study and the helpful review suggestions of Glen D. Carter, Robert C. Averett, and John H. Feth.

\section{GLOSSARY OF SELECTED TERMS}

Aliquot. A known exact part of a whole sample. Alluvial. Deposited by a stream or running water.

Andesite. A dark-colored fine-grained rock formed by the cooling of extruded volcanic magma.

Background. The abundance of an element or substance in an area in which tre concentration is not anomalous.

Basalt. A dark- to medium-dark-colored rock commonly formed by the cooling of extruded volcanic magma.

Baseline information. Information that describes an environmental condition or parameter at the time of study that will permit future comparisons to be made as changes occur.

Bedload. The part of the total sediment of a stream that is moved on or near the streambed. In many streams sand is the main component of bedload.

Bottom sediment. The sediment deposited at the bottom of a water body.

Claystone. An earthy fine-grained sedimentary rock formed by the consolidation of primarily clay-sized particles.

Clay sized. Soil or sediment particles having a diameter of less than $0.002 \mathrm{~mm}(2 \mu \mathrm{m})$.

Detection limit. The lowest concentration of a substance that can be measured by a given 
analytical method. The term is synonymous with sensitivity.

Enrichment. An increase in the concentration of a substance over the natural background concentration. As used in this paper, the term is synonymous with pollution.

Geochemistry. The study of the distribution, amounts, and circulation of the chemical elements in minerals, rocks, soils, water, and the atmosphere.

Glaciofluvial. Pertaining to the melt-water streams flowing from wasting glacier ice and especially to the deposits produced by such streams.

Gravel. An unconsolidated natural accumulation of rounded rock fragments resulting from erosion, consisting predominantly of particles having a diameter of greater than $2 \mathrm{~mm}$.

Micrometre $(\mu \mathrm{m})$. A conventional unit for expressing the diameter of small particles. One micrometre is equal to one thousandth of a millimetre, or $1 / 25,400$ inch.

Modal. Pertaining to the predominant or most frequent magnitude.

Normal probability. A distribution of different values of a variable which follows the Gaussian or "bell shaped" curve.

Organic. Pertaining or relating to a compound containing carbon.

Organometallic complex. A special form of chemical combination between a metal and organic molecules.

Parts per million (ppm). A conventional unit for expressing concentration. For describing the concentration of metals in sediment, the unit expresses the number of parts by weight of the metal per million parts of dry sediment weight. This is equivalent to milligrams of metal per kilogram of dry sediment.

Pollution. Any substance introduced into water that changes the natural quality of the water or associated aquatic system. As used in this paper, the term is synonymous with enrichment.

Reconnaissance. A type of sample or program designed to determine the present status of something; a preliminary survey.

River morphology. The pattern and geometry of a river channel, including the network of tributaries within the drainage basin.

Sand sized. Soil or mineral particles having a diameter in the range of $0.05-2 \mathrm{~mm}$.
Sediment. Fragmental material, both mineral and organic, that is in suspension or is being transported by the water mass or has been deposited on the bottom of the aquatic environment.

Sensitivity. The term is synonymous with detection limit.

Shale. A fine-grained sedimentary rock formed by the consolidation of clay- and silt-sized particles and characterized by a fine parallel structure along which the rock breaks into thin layers.

Silt sized. Soil or sediment particles having a diameter in the range of $0.002-0.05 \mathrm{~mm}(2-50$ $\mu \mathrm{m})$.

Slough. A section of an abandoned river channel containing stagnant or slowly moving water.

Synoptic. The distribution of conditions over a wide area at a given time.

Toxicity. The ability of a substance to cause injury to living tissue once it reaches a susceptible site in or on the organism.

Trace metal. A metal present in minor amounts in the Earth's crust; that is, less than about 0.01 percent.

\section{REFERENCES}

Chu, T. Y., and Davidson, D. T., 1953, Simplified air-jet dispersion apparatus for mechanical analysis of soils: Highway Board Proc., v. 32, p. 441-457.

Glenn, J. L., 1965, Late Quaternary sedimertation and geologic history of the north Willamette Valley, Oregon: Ph.D. thesis submitted to the Graduate School of Oregon State Univ., Corvallis, Oreg., 231 p.

Goldblatt, E. L., Van Denburgh, A. S., and Marsl land, R. A., 1963, The unusual and widespread occurrence of arsenic in well waters of Lane County, Oregon: Euzzene, Oreg., Lane County Dept. Public Health, 24 p.

Harris, D. D., 1968, Travel rates of water for selected streams in the Willamette River basin, Oregon: U.S. Geol. Survey Hydrol. Inv. Atlas HA-273.

Jackson, M. L., 1956, Soil chemical analysis-advanced course [published by author]: Madison, Wisc onsin Univ., $991 \mathrm{p}$.

Jenne, E. A., 1968, Controls on $\mathrm{Mn}, \mathrm{Fe}, \mathrm{Co}, \mathrm{Ni}, \mathrm{Cu}$, and $\mathrm{Zn}$ concentrations in soils and water: the significant role of hydrous $\mathrm{Mn}$ and Fe oxides: Trace inorganics in water, in Advances in chemistry series No. 73, p. 337-387.

Levinson, A. A., 1974, Introduction to exploratior geochemistry: Calgary, Canada, Applied Publ. Co., Ltd., 612 p.

Myers, A. T., Havens, R. G., and Dunton, P. J., 1961, A spectrochemical method for the semiquantitative analysis of rocks, minerals, and ores: U.S. Geol. Survey Bull. 1084-I, p. 207-229.

Oregon Department of Geology and Mineral Industries, 1951, Oregon metal mines handbook-northwestirn Oregon: 
Oregon Dept. Geology and Mineral Industries Rept. 14-D, $166 \mathrm{p}$.

Parker, R. L., 1967, Composition of the earth's crust, in Fleischer, Michael, tech. ed., Data of geochemistry (6th ed.): U.S. Geol. Survey Prof. Paper 440-D, 19 p.

Shacklette, H. T., Hamilton, J. C., Boerngen, J. G., and Bowles, J. M., 1971, Elemental composition of surficial materials in the conterminous United States: U.S. Geol. Survey Prof. Paper 545-D, 71 p.

U.S. Army Corps of Engineers, 1973, Aerial mosaics, Willamette River, May 2, 1972: Portland, Oreg., U.S. Army Engineer Dist., 57 p.

Velz, C. J., 1961, Supplementary report on lower Willamette River waste assimilation capacity: Natl. Council for Stream Improvement of Pulp, Paper, and Paperboard In- dustries, Inc., School of Public Health, Michigan Univ., Ann Arbor, 28 p.

-1970, Applied stream sanitation: $\mathrm{Ne}^{-\times \pi}$ York, John Wiley \& Sons, Inc., 619 p.

Ward, F. N., Lakin, H. W., Canney, F. C., and others, 1963, Analytical methods used in geochemical exploration by the U.S. Geological Survey: U.S. Geol. Survey Bull. 1152, $100 \mathrm{p}$.

Ward, F. N., Nakagawa, H. M., Harms, T. F., and Van Sickle G. H., 1969, Atomic-absorption methods of analysis useful in geochemical exploration: U.S. Geol. Survey Bull. 1289, $45 \mathrm{p}$.

Willamette Basin Task Force, 1969, Willamette Basin comprehensive study of water and related land resources, Appendix A, Study area: Pacific Northwest River Basins Comm. rept., 103 p. 
TABLES 9-15 
TABLE 9.-Site descriptions and physical characteristics of bottom sediments from the Willamette River and adjacent waters

\begin{tabular}{|c|c|c|c|c|c|c|}
\hline $\begin{array}{l}\text { Sample } \\
\text { number }\end{array}$ & Site description ${ }^{1}$ & $\begin{array}{l}\text { Location in } \\
\text { cross section }\end{array}$ & $\begin{array}{l}\text { Water } \\
\text { depth } \\
\text { (ft) }\end{array}$ & $\begin{array}{c}\text { Field } \\
\text { observations }\end{array}$ & $\begin{array}{c}\text { Weight } \\
\text { percentage } \\
=2 \mathrm{~mm}\end{array}$ & $\begin{array}{c}\text { Description } \\
>2 \text {-mm } \\
\text { materials }\end{array}$ \\
\hline 1 & Columbia River; ${ }^{1}$ is mi below Portland sewage treatment plant & $1 / 4$ & 33 & Sandy & 2 & Gravel. \\
\hline 2 & Columbia Slough; ${ }^{1}{ }_{4}$ mi from Willamette River & $1 / 2$ & 10 & Fine materials, dark color & 1 & Wood. \\
\hline$\overline{3}$ & 1.5 ; opposite G. Grebe's house & $1 / 3$ & 43 & Fine materials & 0 & \\
\hline 4 & 1., opposite G. Grede s nouse & $1 / 4$ & 40 & Fine mate do & 0 & \\
\hline 5 & do & $1 / 2$ & 40 & do & 0 & \\
\hline 6 & do & $3 / 4$ & 40 & do & 0 & \\
\hline 7 & Multnomah Channel; ${ }^{1} 4 \mathrm{~m}$ below Gray's Moorage & $1 / 3$ and $1 / 2$ & 20 & Sandy, some gravel & 10 & Gravel. \\
\hline 8 & $6.0 ;$ just below St. Johns Bridge & $1 / 2$ & 43 & Wandy, so do graver - & 8 & Do. \\
\hline 9 & $8.1 ; 300$ yards inside Swan Island Channel & $1 / 2$ & 36 & Fine materials & 0 & \\
\hline 10 & $8.5 ;$ off Swan Island & $1 / 2$ & 60 & $\ldots$ do & 0 & \\
\hline 11 & do & $1 / 4$ & 30 & do & 0 & \\
\hline 12 & do & $1 / 2$ & 60 & - & 0 & \\
\hline 13 & do & $3 / 4$ & 30 & do $\ldots$ & $<1$ & Gravel. \\
\hline 14 & 11.7; below Broadway Bridge & $1 / 2$ & 42 & Sandy & 2 & Gravel and wood. \\
\hline 15 & 13.7; above Marquam Bridge & $1 / 3$ & 22 & Sand and fine materials & $<1$ & Wood. \\
\hline 16 & $17.0 ;^{1} \mathrm{mi}$ above Sellwood Bridge & $1 / 2$ & 66 & Fine materials, odorous & $<1$ & Wood. \\
\hline 17 & $21.1: 200$ yards above Lake Oswego confluence & $1 / 2$ & 60 & Gravelly and sandy & 54 & Gravel. \\
\hline 18 & Clackamas River; $1000 \mathrm{ft}$ below bridge on State Hwy. $99 \mathrm{E}$ & $1 / 10$ & 1 & Sandy & 1 & Do. \\
\hline 19 & 25.6: opposite Sportcraft Landing & $1 / 2$ & 15 & Very gravelly & 76 & Do. \\
\hline 20 & 27.9 ;ust below Oregon City Marina & $1 / 3$ & 27 & Gravelly & 49 & Do. \\
\hline 21 & Tualatin River; $500 \mathrm{ft}$ from Willamette River & $1 / 20$ & 3 & Sandy & 18 & Gravel and wood. \\
\hline 22 & $34.1 ; 1_{4}^{1 / 4} \mathrm{mi}$ below Canby ferry & $1 / 3$ & 60 & Very gravelly & 81 & Gravel. \\
\hline 23 & $34.9 ; 1,2 \mathrm{mi}$ above Canby ferry & $1 / 4$ & 25 & Sandy, black, gas bubbles & 0 & \\
\hline 24 & 45.8; just below Champoeg Park & $1 / 4$ & 30 & Fine materials & 0 & \\
\hline 25 & 48.6: $500 \mathrm{ft}$ above New Newberg Bridge & $1 / 4$ & 15 & Fine materials, odorous & 1 & Gravel and wood. \\
\hline 26 & 50.2 ; just above Publishers Paper outfall & $2 / 3$ & 33 & Sludgy, fine materials & 0 & \\
\hline 27 & 54.0 ; about $1 \mathrm{mi}$ below confluence of Yamhill River & $4 / 5$ & 22 & Fine materials, odorous & $<1$ & Gravel. \\
\hline 28 & $69.0 ;$ near Tompkins Bar & $1 / 10$ and $9 / 10$ & $5-10$ & Sandy & 1 & Wood. \\
\hline 29 & Boise Cascade Slough; $500 \mathrm{ft}$ from Willamette River & $1 / 2$ & 14 & $\begin{array}{l}\text { Fine materials, black, } \\
\text { gas bubbles. }\end{array}$ & $<1$ & Wood and paper. \\
\hline 30 & 86.7: above Boise Cascade outfall & $9 / 10$ & 6 & Gravelly and sandy .. & 29 & Gravel. \\
\hline 31 & Santiam River; at railroad bridge & $5 / 6$ & 7 & do & 7 & Do. \\
\hline 32 & 112.6: Spring Hill Rocks near Conser Road & $1 / 10$ and $9 / 10$ & $2-3$ & do & 13 & Do. \\
\hline 33 & Head of Fourth Lake & $1 / 2$ & 3 & Black and oily, gas bubbles & 0 & \\
\hline 34 & Center of Fourth Lake & $1 / 2$ & 10 & Drate do & 0 & \\
\hline 35 & Fourth Lake near confluence with Willamette River & $1 / 2$ & 10 & do $\ldots$ & $<1$ & Wood. \\
\hline 36 & 117.0: below Albany sewage-treatment plant & $1 / 10$ and $9 / 10$ & $\begin{array}{r}10 \\
2\end{array}$ & Sand and fine materials & 1 & Gravel and wood. \\
\hline 37 & 120; above Calapooia River & $1 / 10$ and $4 / 5$ & $3-12$ & a in an do the & 1 & Wood. \\
\hline 38 & 1301 : below Corvallis & $9 / 10$ & $\begin{array}{c}5-12 \\
6\end{array}$ & Fine materials & 3 & Gravel and wood. \\
\hline 39 & Marys River; beneath highway bridge near Willamette River -- & $1 / 2$ and $4 / 5$ & $6-8$ & Sandy & 3 & Do. \\
\hline 40 & $141.3 ;$ just below Peoria & $9 / 10$ & 2 & do & 2 & Do. \\
\hline 41 & 161.2; near highway bridge at Harrisburg & $4 / 5$ & 12 & do & 2 & Do. \\
\hline 42 & 178.1; near Beltline Bridge below Eugene & $9 / 10$ & 3 & Gravelly and sandy & 8 & Gravel. \\
\hline 43 & 185.3; near bridge on State Hwy. 126 & $1 / 10$ & 4 & Very gravelly & 56 & Gravel, some snails. \\
\hline 44 & Coast Fork near bridge on State Hwy. 58 & $9 / 10$ & 4 & - & 79 & Gravel. \\
\hline
\end{tabular}

${ }^{1}$ River mile locations in Willamette River according to revised U.S. Army Corps of Engineers index system.

${ }^{2}$ From left bank.

TABLE 10.-Particle-size composition of bottom sediments from the Willamette River and adjacent waters

\begin{tabular}{|c|c|c|c|c|c|c|c|c|c|c|c|}
\hline \multirow[b]{2}{*}{$\begin{array}{l}\text { Sample } \\
\text { number }\end{array}$} & \multirow[b]{2}{*}{ Site } & \multicolumn{4}{|c|}{ Particle-size composition ${ }^{1}$} & \multirow[b]{2}{*}{$\begin{array}{l}\text { Sample } \\
\text { number }\end{array}$} & \multirow[b]{2}{*}{ Site } & \multicolumn{4}{|c|}{ Particle-size composition $^{1}$} \\
\hline & & $\begin{array}{c}\text { Sand } \\
\mid 2 \mathrm{~mm}- \\
50 \mu \mathrm{m} \mid\end{array}$ & $\begin{array}{c}\text { Silt } \\
(50 \mu \mathrm{m}- \\
2 \mu \mathrm{m})\end{array}$ & $\underset{(<2 \mu \mathrm{m})}{\text { Clay }}$ & $<20 \mu \mathrm{m}^{2}$ & & & $\begin{array}{c}\text { Sand } \\
(2 \mathrm{~mm}- \\
50 \mu \mathrm{m})\end{array}$ & $\begin{array}{c}\text { Silt } \\
(50 \mu \mathrm{m}- \\
2 \mu \mathrm{m})\end{array}$ & $\begin{array}{c}\text { Cley } \\
(<2 \mu \mathrm{m})\end{array}$ & $<20 \mu \mathrm{m}^{2}$ \\
\hline 1 & Columbia River - & 96 & 3 & 1 & 2 & 25 & 48.6 . & 63 & 33 & 4 & 25 \\
\hline 2 & Columbia Slough & 39 & 56 & $\frac{1}{5}$ & 34 & 26 & 50.2 & 23 & 67 & $\begin{array}{r}4 \\
10\end{array}$ & 57 \\
\hline 3 & 1.5 & 22 & 70 & 8 & $\begin{array}{l}34 \\
46\end{array}$ & $\begin{array}{l}20 \\
27\end{array}$ & $54.0 \ldots$ & 37 & 56 & 7 & 47 \\
\hline 4 & $1.5-10-10$ & 30 & 64 & 6 & 39 & 28 & 69.0 & 86 & 13 & $i$ & 9 \\
\hline 5 & 1.5 & 30 & $\begin{array}{l}04 \\
62\end{array}$ & 8 & 45 & 29 & Boise Cascade Slough & $\begin{array}{l}\infty 0 \\
12\end{array}$ & 77 & 11 & 65 \\
\hline 6 & $1.5-2-10-10-1$ & 13 & 78 & 9 & 59 & 30 & 86.7 & 75 & 23 & 2 & 17 \\
\hline 7 & Multnomah Channel & 91 & 8 & 1 & 5 & 31 & Santiam River & 82 & 16 & 2 & 11 \\
\hline 8 & 6.0 & 89 & 10 & 1 & 8 & 32 & 112.6 & 89 & 10 & 1 & 7 \\
\hline 9 & Swan Island Channel & 5 & 84 & 11 & 66 & 33 & Head of Fourth Lake & 0 & 85 & 15 & 70 \\
\hline 10 & 8.5 & 22 & 71 & 7 & 45 & 34 & Middle of Fourth & 0 & 85 & 15 & 70 \\
\hline 11 & 8.5 & 3 & 89 & 8 & 63 & & Lake. & & & & \\
\hline 12 & 8.5 & 24 & 69 & 7 & 45 & 35 & Fourth Lake near & 10 & 82 & 8 & 60 \\
\hline 13 & 8.5 & 37 & 58 & $\dot{5}$ & 36 & & confluence. & & & & \\
\hline 14 & 11.7 & 88 & 11 & 1 & 6 & 36 & 117.0 & 67 & 30 & 3 & 22 \\
\hline 15 & 13.7 & 67 & 30 & 3 & 18 & 37 & 120.0 & 65 & 31 & 4 & 21 \\
\hline 16 & 17.0 & 28 & 65 & 7 & 40 & 38 & 130.1 & 52 & 43 & 5 & 28 \\
\hline 17 & 21.1 & 81 & 18 & 1 & 12 & 39 & Marys River & 72 & 24 & 4 & 16 \\
\hline 18 & Clackamas River & 93 & 7 & 0 & 4 & 40 & 141.3 & 81 & 17 & 2 & 13 \\
\hline 19 & 25.6 & 94 & 6 & 0 & 6 & 41 & 161.2 & 87 & 11 & 2 & 8 \\
\hline 20 & 27.9 & 80 & 18 & 2 & 12 & $\begin{array}{l}41 \\
42\end{array}$ & $\begin{array}{l}101.2 \ldots-\ldots \\
178.1\end{array}$ & 94 & 5 & 1 & $\stackrel{\circ}{2}$ \\
\hline 21 & Tualatin River & 84 & 15 & $\vec{\imath}$ & 5 & 43 & 185.3 & 91 & 8 & 1 & 2 \\
\hline 22 & 34.1 & 43 & 52 & 5 & 37 & 44 & Coast Fork at & 61 & 34 & 5 & 27 \\
\hline 23 & 34.9 & 77 & 21 & 2 & 14 & & Highway 58 . & & & & \\
\hline 24 & 45.8 & 44 & 50 & 6 & 39 & & & & & & \\
\hline
\end{tabular}

${ }_{1}^{1}$ Percentage by weight of dry sediment. Size analysis and separation by Charles Ollery, Oregon State University.

${ }^{2}$ The $<20-\mu \mathrm{m}$ materials contain the clay fraction plus part of the silt (fine silt) fraction of each sample. 
TABLE 11.-Checklist of element names and symbols

\begin{tabular}{|c|c|c|}
\hline Element & Element & Element \\
\hline 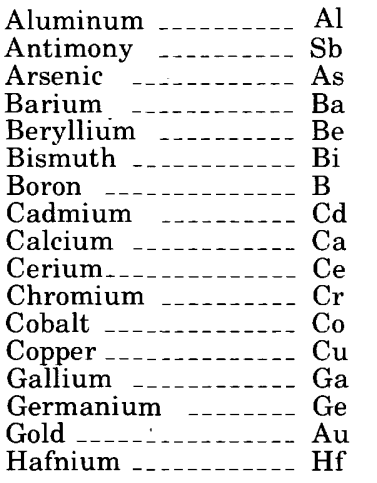 & 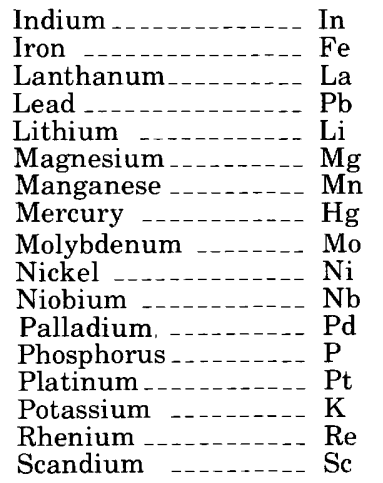 & 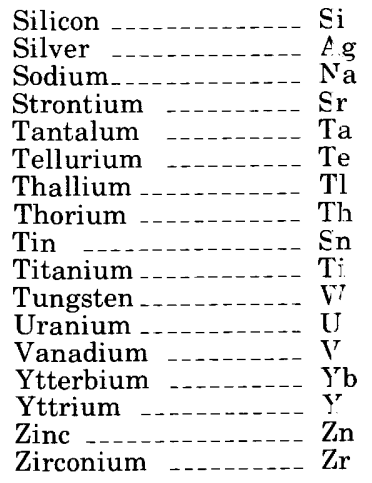 \\
\hline
\end{tabular}

TABLE 12.-Concentrations (percentage by weight) of major elements in bottom sediments from the Willamette River and adjacent waters ${ }^{1}$

\begin{tabular}{|c|c|c|c|c|c|c|c|c|c|c|c|c|c|c|c|}
\hline \multirow[b]{3}{*}{$\begin{array}{l}\text { Sample } \\
\text { Number }\end{array}$} & \multirow[b]{3}{*}{ Site } & \multicolumn{10}{|c|}{ Emission spectroscopy ${ }^{2}$} & \multicolumn{4}{|c|}{$\begin{array}{l}\text { Atomic absorption } \\
\text { spectrophotometry }\end{array}$} \\
\hline & & \multicolumn{10}{|c|}{$<20-\mu \mathrm{m}$ materials } & \multicolumn{2}{|c|}{$<2 \mathrm{~mm}^{4}$} & \multicolumn{2}{|c|}{$<20 \mu \mathrm{m}$} \\
\hline & & $\mathrm{Si}$ & $\mathrm{Al}$ & $\mathrm{Ca}$ & $\mathrm{Mg}$ & $\mathrm{Na}$ & $\mathbf{K}$ & $\mathrm{Ti}$ & $\mathbf{P}$ & $\mathrm{Fe}$ & $\mathrm{Mn}$ & $\mathrm{Fe}$ & $\mathrm{Mn}$ & $\mathrm{Fe}$ & $\mathrm{Mn}$ \\
\hline 1 & Columbıa River - & $>10$ & 10 & 3 & 1.5 & 2 & 3 & 0.7 & $<0.2$ & 7 & 0.15 & 0.8 & 0.012 & 3.6 & 0.087 \\
\hline 2 & Columbia Slough & $>10$ & 10 & 2 & 1.5 & 1.5 & 3 & .7 & $<.2$ & 7 & .1 & 1.9 & .040 & 2.4 & .062 \\
\hline 3 & 1.5 & $(5)$ & & 2 & & & & & & $-\overline{0}$ & & 2.3 & .048 & 2.5 & .069 \\
\hline 4 & 1.5 & $>10$ & 10 & 2 & 1.5 & 1.5 & 2 & .7 & $<.2$ & 7 & 1 & 2.3 & .042 & 3.0 & .062 \\
\hline 5 & 1.5 & & & & & & -- & & & -- & & 2.7 & .054 & 3.6 & .065 \\
\hline 6 & 1.5 & $>10$ & 10 & 2 & 1.5 & 1 & 2 & .7 & $<.2$ & 7 & .1 & 2.6 & .062 & 3.6 & .073 \\
\hline 7 & Multnomah Channel & $>10$ & 10 & 2 & 1.5 & 1 & 1.5 & .7 & $<.2$ & 10 & .3 & 1.5 & .045 & 4.4 & .260 \\
\hline 8 & 6.0 & $>10$ & 10 & 2 & 1.0 & 1 & 2 & .7 & $<.2$ & 7 & .15 & 1.4 & .027 & 4.4 & .110 \\
\hline 9 & Swan Island Channel & $>10$ & 10 & 2 & 1.5 & 1 & 1.5 & 1.0 & $<.2$ & 7 & .15 & 3.1 & .062 & 2.7 & 061 \\
\hline 10 & 8.5 & & & & & -- & & & & & & 2.8 & .072 & 3.0 & .086 \\
\hline 11 & 8.5 & $>10$ & 10 & 2 & 1.5 & 1 & 1.5 & .7 & $<. \overline{2}$ & 7 & .1 & 3.0 & .059 & 2.7 & .065 \\
\hline 12 & 8.5 & $>10$ & 10 & 2 & 1.5 & 1 & 2 & .7 & $<.2$ & 7 & .1 & 2.4 & .044 & 3.1 & .068 \\
\hline 13 & 8.5 & $>10$ & $>10$ & 2 & 1.5 & 1.5 & 1.5 & .7 & $<.2$ & 7 & .1 & 2.8 & .053 & 3.4 & .067 \\
\hline 14 & 11.7 & $>10$ & 10 & 2 & 1.5 & 1 & 1.5 & .7 & $<.2$ & 7 & .15 & 1.4 & .022 & 3.9 & .096 \\
\hline 15 & 13.7 & $>10$ & 10 & 2 & 1.5 & 1 & 1 & .7 & $<.2$ & 7 & .15 & 1.8 & .034 & 3.7 & .086 \\
\hline 16 & 17.0 & $>10$ & 10 & 1.5 & 1.5 & .7 & 1 & .7 & $<.2$ & 7 & 15 & 2.5 & .075 & 3.4 & .110 \\
\hline 17 & 21.1 & $>10$ & 10 & 1.5 & 1.5 & .7 & 1 & .7 & $<.2$ & 7 & 15 & 1.9 & .050 & . 3.6 & .130 \\
\hline 18 & Clackamas River & $>10$ & 10 & 2 & 1.5 & 1 & 1.5 & .7 & $<.2$ & 7 & .15 & 1.7 & .029 & 3.8 & .120 \\
\hline 19 & 25.6 & $>10$ & 10 & 2 & 1.5 & .7 & 1 & 1.0 & $<.2$ & 7 & .15 & 1.7 & .037 & 2.6 & .130 \\
\hline 20 & 27.9 & $>10$ & 10 & 2 & 1.5 & 1 & 1 & .7 & $<.2$ & 7 & .15 & 2.2 & .044 & 4.2 & .120 \\
\hline 21 & Tualatin River & $>10$ & 10 & 2 & 1.5 & 1 & 1.5 & .7 & $<.2$ & 7 & .15 & 2.0 & .045 & & \\
\hline 22 & 34.1 & & & & & & & & & & & 2.6 & .066 & 3.5 & .110 \\
\hline 23 & $34.9-2-1$ & $>10$ & 10 & 2 & $1 . \overline{5}$ & 1 & $1 . \overline{5}$ & .7 & $<. \overline{2}$ & 7 & .15 & 2.1 & .034 & 4.1 & .089 \\
\hline 24 & $45.8-2$. & $>10$ & 10 & $\overline{2}$ & 1.5 & 1 & 1 & .7 & $<.2$ & 7 & .1 & 2.9 & .073 & 3.6 & .089 \\
\hline 25 & 48.6 & $>10$ & 10 & 1 & 1.5 & .7 & .7 & .7 & $<.2$ & 5 & .15 & 2.3 & .049 & 3.7 & .110 \\
\hline 26 & 50.2 & $>10$ & 10 & 1.5 & 1.5 & $1 \ddot{1}$ & 1 & .7 & $<.2$ & 5 & .1 & 2.8 & .080 & 3.2 & .092 \\
\hline 27 & 54.0 & $>10$ & 10 & 1.5 & 1.5 & 1 & .7 & .7 & $<.2$ & 7 & .15 & 2.6 & .097 & 3.6 & .120 \\
\hline 28 & 69.0 & $>10$ & 10 & 1.5 & 1.5 & 1.5 & 1 & .7 & $<.2$ & 7 & 1 & 2.0 & .036 & 4.8 & .076 \\
\hline 29 & Boise Cascade Slough & $>10$ & $>10$ & 1 & 1.5 & 1 & 1.5 & .7 & $<.2$ & 7 & .07 & 2.6 & .046 & 3.5 & .056 \\
\hline 30 & 86.7 & $>10$ & 10 & 2 & 1.5 & .7 & .7 & .7 & $<.2$ & 7 & .15 & 2.1 & .051 & 4.3 & .120 \\
\hline 31 & Santiam River & $>10$ & 10 & $\overline{2}$ & 1.5 & .7 & .7 & .7 & $<.2$ & 7 & .1 & 2.0 & .040 & 4.1 & .089 \\
\hline 32 & 112.6 & $>10$ & 10 & 3 & 1.5 & 1 & $1 \ddot{1}$ & .7 & $<.2$ & 7 & .15 & .93 & .023 & 3.9 & .110 \\
\hline 33 & Head-Fourth Lake & $>10$ & 7 & 1.5 & .7 & 1 & 1 & .3 & $<.2$ & 3 & .07 & .19 & .070 & 3.9 & .052 \\
\hline 34 & Middle-Fourth Lake & $>10$ & 7 & 1.5 & .7 & 1 & 1 & .3 & $<.2$ & 3 & .07 & .69 & .037 & 3.1 & .052 \\
\hline 35 & Fourth Lake near confluence & $>10$ & 10 & 2 & 1.5 & .7 & .7 & .5 & $<.2$ & 5 & .05 & 1.5 & .020 & 2.9 & .026 \\
\hline 36 & 117.0 & $>10$ & 10 & 2 & 1.5 & .7 & .7 & .7 & $<.2$ & 7 & .1 & 1.8 & .030 & 3.9 & .062 \\
\hline 37 & 120.0 & $>10$ & 10 & 1.5 & 1.5 & 1 & .7 & .7 & $<.2$ & 7 & .1 & 1.5 & .039 & 3.1 & .084 \\
\hline 38 & 130.1 & $>10$ & 10 & 2 & 1.5 & 1 & 1 & .7 & $<.2$ & 7 & .07 & 1.1 & .021 & 6.0 & .300 \\
\hline 39 & Marys River & $>10$ & 10 & 1.5 & 2 & .7 & 1.5 & .7 & $<.2$ & 7 & .2 & 1.5 & .090 & 2.9 & .037 \\
\hline 40 & 141.3 & $>10$ & 10 & 2 & 1.5 & $1 \ddot{1}$ & 1 & .7 & $<.2$ & 7 & 1 & 1.4 & .021 & 3.9 & .071 \\
\hline 41 & 161.2 & $>10$ & 10 & 2 & 1.5 & 1.5 & $\hat{1}$ & .7 & $<.2$ & 7 & .15 & 1.4 & .028 & 4.2 & .970 \\
\hline 42 & 178.1 & $>10$ & 10 & 3 & 1.5 & 1 & .7 & .7 & $<.2$ & 7 & .15 & 1.3 & .027 & 2.8 & .022 \\
\hline 43 & - & $>10$ & 7 & 1 & 1.0 & .5 & $<.7$ & .5 & $<.2$ & 7 & .15 & 1.3 & .034 & & \\
\hline 44 & Coast Fork & $>10$ & 7 & .7 & .7 & .5 & $<.7$ & .5 & $<.2$ & 5 & .2 & 1.9 & .120 & 3.3 & .250 \\
\hline
\end{tabular}

'To obtain concentrations in parts per million, multiply weight percentages by 10,000 .

${ }^{2}$ Emission spectroscopy includes metals contained in crystal lattices. Analyses by Ray G. Havens.

${ }^{3}$ Analyses by Kam W. Leong.

4The $<2$-mm materials contain the $<20 . \mu \mathrm{m}$ fraction.

5 Not determined. 
TABLE 13.-Trace metals having concentrations in all sediment samples below detection limits of the emission-spectrographic method ${ }^{1}$

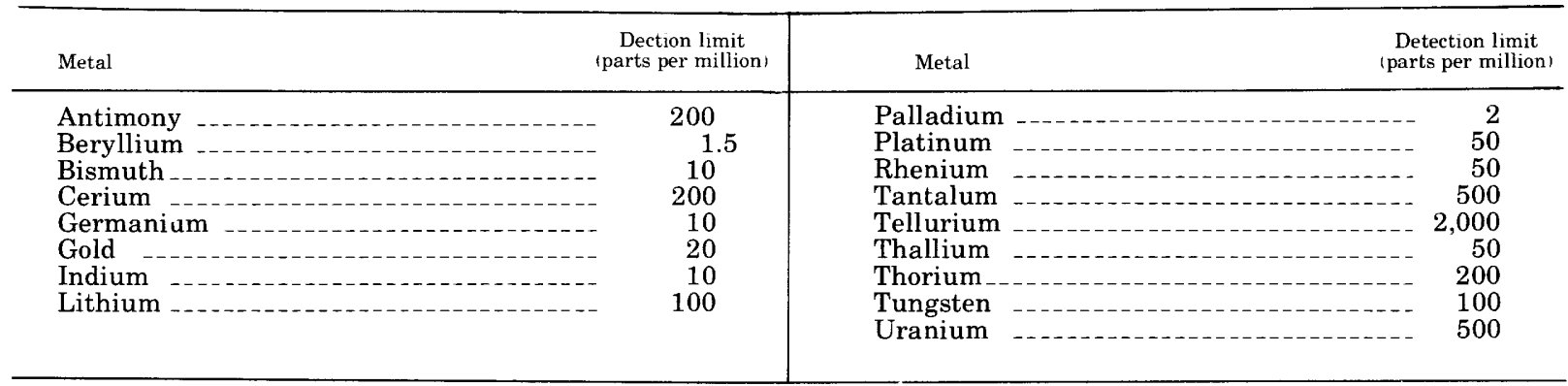

${ }^{1}$ Arsenıc and cadmium were below the detection limits but were later determined by wet chemical methods. (See table 3 .) Spectrographic analyses were by Ray G. Havers.

TABLE 14.-Concentrations (in parts per million) of trace elements in $<20$ - $\mu$ m materials of bottom sediments from the Willamette River and adjacent waters

[All analyses by emission spectroscopy] ${ }^{1}$

\begin{tabular}{|c|c|c|c|c|c|c|c|c|c|c|c|c|c|c|c|c|c|c|c|c|c|c|}
\hline $\begin{array}{l}\text { Sample } \\
\text { number }\end{array}$ & Site & $\mathrm{Ba}$ & B & $\mathrm{Cr}$ & $\mathrm{Co}$ & $\mathrm{Cu}$ & $\mathrm{Ga}$ & $\mathrm{Hf}$ & La & $\mathrm{Pb}$ & Mo & $\mathrm{Ni}$ & $\mathrm{Nb}$ & $\mathrm{Sc}$ & $\mathrm{Ag}$ & $\mathrm{Sr}$ & Sn & V & $\mathrm{Yb}$ & $\mathrm{Y}$ & $\mathrm{Zn}$ & $\mathrm{Zr}$ \\
\hline 1 & $\begin{array}{l}\text { Columbia } \\
\text { River. }\end{array}$ & 1,000 & 700 & 70 & 30 & 150 & 15 & $<100$ & $<50$ & 100 & $<3$ & 50 & $<10$ & 30 & 3.0 & 700 & $<10$ & 150 & 5 & 50 & 700 & 200 \\
\hline 2 & $\begin{array}{l}\text { Columbia } \\
\text { Slough. }\end{array}$ & 700 & 50 & 70 & 20 & 70 & 15 & $<100$ & $<50$ & 70 & $<3$ & 30 & $<10$ & 30 & $<.5$ & 500 & $<10$ & 150 & 3 & 30 & $<300$ & 150 \\
\hline $\begin{array}{l}3 \\
4\end{array}$ & $\begin{array}{l}1.5-1.5-1 \\
1.5\end{array}$ & $\begin{array}{r}\left.t^{2}\right) \\
700\end{array}$ & 20 & 70 & 20 & $\overline{70}$ & 15 & $<100$ & $<50$ & 70 & $<3$ & 30 & $<10$ & 30 &.$\overline{5}$ & 500 & $<10$ & 150 & 3 & 30 & 300 & 150 \\
\hline $\begin{array}{l}5 \\
6\end{array}$ & $\begin{array}{l}1.5 \ldots-\cdots \\
1.5\end{array}$ & 700 & $<20$ & 70 & 20 & & 15 & & $<50$ & 70 & $<3$ & & & & & & & & & & & \\
\hline 7 & $\begin{array}{l}\text { Multnomah } \\
\text { Channel. }\end{array}$ & 700 & 150 & 70 & 50 & $\begin{array}{l}70 \\
70\end{array}$ & $\begin{array}{l}15 \\
15\end{array}$ & $\begin{array}{l}<100 \\
<100\end{array}$ & $\begin{array}{l}<50 \\
<50\end{array}$ & $\begin{array}{l}70 \\
70\end{array}$ & $\begin{array}{l}<3 \\
<3\end{array}$ & $\begin{array}{l}30 \\
50\end{array}$ & $\begin{array}{l}<10 \\
<10\end{array}$ & $\begin{array}{l}30 \\
30\end{array}$ & $\begin{array}{r}.5 \\
<.5\end{array}$ & $\begin{array}{l}700 \\
300\end{array}$ & $\begin{array}{l}<10 \\
<10\end{array}$ & $\begin{array}{l}150 \\
150\end{array}$ & $\begin{array}{l}3 \\
3\end{array}$ & $\begin{array}{l}30 \\
30\end{array}$ & $\begin{array}{l}300 \\
500\end{array}$ & $\begin{array}{l}150 \\
200\end{array}$ \\
\hline 8 & 6.0 & 700 & 100 & 70 & 30 & 70 & 15 & $<100$ & $<50$ & 70 & $<3$ & 30 & $<10$ & 30 & .5 & 300 & $<10$ & 150 & 3 & 30 & 300 & 200 \\
\hline 9 & $\begin{array}{l}\text { Swan Island } \\
\text { Channel. }\end{array}$ & 500 & $<20$ & 70 & 20 & 100 & 15 & $<100$ & $<50$ & 70 & $<3$ & 30 & $<10$ & 30 & .5 & 500 & $<10$ & 150 & 3 & 30 & $<300$ & 200 \\
\hline $\begin{array}{l}10 \\
11\end{array}$ & $\begin{array}{l}8.5 \\
8.5\end{array}$ & 500 & $<20$ & 70 & 20 & 70 & 15 & $<100$ & $<50$ & 70 & $<\overline{3}$ & 30 & $<10$ & 30 & 5 & 500 & $<10$ & & 3 & 30 & 300 & 150 \\
\hline 12 & 8.5 & 700 & $\begin{array}{r}20 \\
20\end{array}$ & 70 & 20 & 70 & $\begin{array}{l}15 \\
15\end{array}$ & $<100$ & $<50$ & 70 & $\begin{array}{l}<3 \\
<3\end{array}$ & $\begin{array}{l}30 \\
30\end{array}$ & $\begin{array}{l}<10 \\
<10\end{array}$ & $\begin{array}{l}30 \\
30\end{array}$ & $\begin{array}{l}.0 \\
.5\end{array}$ & $\begin{array}{l}500 \\
500\end{array}$ & $\begin{array}{l}<10 \\
<10\end{array}$ & $\begin{array}{l}150 \\
150\end{array}$ & $\begin{array}{l}3 \\
3\end{array}$ & $\begin{array}{l}30 \\
50\end{array}$ & $\begin{array}{l}300 \\
300\end{array}$ & $\begin{array}{l}150 \\
200\end{array}$ \\
\hline 13 & $8.5 \ldots$ & 500 & 30 & 70 & 20 & 70 & 15 & $<100$ & $<50$ & 70 & $<3$ & 30 & $<10$ & 30 & .5 & 700 & $<10$ & 150 & 3 & 30 & $<300$ & 200 \\
\hline 14 & $11.7 \ldots$ & 500 & 150 & 70 & 20 & 70 & 15 & $<100$ & $<50$ & 150 & $<3$ & 30 & $<10$ & 30 & 1.5 & 500 & $<10$ & 150 & 3 & 30 & 500 & 200 \\
\hline 15 & 13.7 & 500 & 50 & 70 & 20 & 70 & 15 & $<100$ & $<50$ & 70 & $<3$ & 30 & $<10$ & 30 & 1.0 & 300 & $<10$ & 150 & 3 & 30 & 500 & 200 \\
\hline 16 & $17.0 \ldots$ & 500 & 20 & 70 & 20 & 70 & 15 & $<100$ & $<50$ & 50 & $<3$ & 30 & $<10$ & 30 & 1.0 & 300 & $<10$ & 150 & 3 & 30 & 700 & 200 \\
\hline 17 & $21.1 \ldots$ & 500 & 50 & 70 & 20 & 100 & 15 & $<100$ & $<50$ & 70 & $<3$ & 30 & $<10$ & 30 & 1.5 & 200 & $<10$ & 150 & 3 & 30 & 700 & 200 \\
\hline 18 & $\begin{array}{l}\text { Clackamas } \\
\text { River. }\end{array}$ & 700 & 300 & 70 & 30 & 70 & 15 & $<100$ & $<50$ & 30 & $<3$ & 30 & $<10$ & 30 & 1.0 & 300 & $<10$ & 150 & 3 & 30 & $<300$ & 200 \\
\hline 19 & $25.6 \ldots$ & 500 & 150 & 70 & 20 & 50 & 15 & $<100$ & $<50$ & 150 & $<3$ & 30 & $<10$ & 30 & 1.0 & 300 & 15 & 150 & 3 & 30 & $<300$ & 200 \\
\hline 20 & 27.9 & 500 & 100 & 70 & 30 & 70 & 15 & $<100$ & $<50$ & 20 & $<3$ & 30 & $<10$ & 30 & $<.5$ & 300 & $<10$ & 150 & 3 & 30 & $<300$ & 200 \\
\hline 21 & $\begin{array}{l}\text { Tualatin } \\
\text { River. }\end{array}$ & 700 & 300 & 70 & 30 & 70 & 15 & $<100$ & $<50$ & 100 & $<3$ & 30 & $<10$ & 30 & .5 & 300 & $<10$ & 150 & 3 & 30 & $<300$ & 150 \\
\hline 22 & $34.1 \ldots$ & & & & & & & & & & & & & & & & & & & & & \\
\hline 23 & 34.9 & 500 & 70 & 70 & 20 & 70 & 15 & $<100$ & $<50$ & 50 & $<\overline{3}$ & 30 & $<10$ & 30 & 1.5 & 500 & $<10$ & 150 & 3 & 30 & $<300$ & 200 \\
\hline 24 & 45.8 & 500 & 20 & 70 & 20 & 70 & 15 & $<100$ & $<50$ & 20 & $<3$ & 30 & $<10$ & 30 & .7 & 300 & $<10$ & 150 & 3 & 30 & $<300$ & 200 \\
\hline 25 & $48.6 \ldots$ & 500 & 20 & 70 & 20 & 70 & 15 & $<100$ & $<50$ & 50 & $<3$ & 30 & $<10$ & 30 & 1.5 & 200 & $<10$ & 150 & 3 & 30 & $<300$ & 200 \\
\hline 26 & 50.2 & 500 & $<20$ & 70 & 15 & 70 & 15 & $<100$ & $<50$ & 50 & $<3$ & 30 & $<10$ & 30 & 1.5 & 300 & $<10$ & 150 & 3 & 30 & $<300$ & 150 \\
\hline 27 & $54.0 \ldots$ & 500 & $<20$ & 70 & 15 & 70 & 15 & $<100$ & $<50$ & 50 & $<3$ & 30 & $<10$ & 30 & 1.5 & 300 & $<10$ & 150 & 3 & 30 & $<300$ & 200 \\
\hline 28 & $69.0 \ldots$ & 500 & 70 & 70 & 20 & 70 & 15 & $<100$ & $<50$ & 30 & $<3$ & 30 & $<10$ & 30 & .5 & 500 & $<10$ & 150 & 3 & 30 & $<300$ & 150 \\
\hline 29 & $\begin{array}{l}\text { Boise Cas- } \\
\text { cade Slough. }\end{array}$ & 500 & $<20$ & 70 & 20 & 70 & 15 & $<100$ & $<50$ & 150 & $<3$ & 30 & $<10$ & 30 & $<.5$ & 300 & $<10$ & 150 & 3 & 30 & $<300$ & 150 \\
\hline 30 & 86.7 & 500 & 30 & 70 & 30 & 70 & 15 & $<100$ & $<50$ & 70 & $<3$ & 30 & $<10$ & 30 & .5 & 300 & $<10$ & 150 & 3 & 30 & $<300$ & 200 \\
\hline 31 & $\begin{array}{l}\text { Santiam } \\
\text { River. }\end{array}$ & 300 & 50 & 50 & 20 & 70 & 15 & $<100$ & $<50$ & 30 & $<3$ & 30 & $<10$ & 30 & $<.5$ & 300 & $<10$ & 100 & 3 & 30 & $<300$ & 150 \\
\hline 32 & 112.6 & 500 & 150 & 70 & 30 & 70 & 15 & $<100$ & $<50$ & 20 & $<3$ & 30 & $<10$ & 30 & $<.5$ & 500 & $<10$ & 100 & 3 & 30 & $<300$ & 150 \\
\hline 33 & $\begin{array}{l}\text { Head-Fourth } \\
\text { Lake. }\end{array}$ & 500 & $<20$ & 100 & 10 & 150 & 15 & 700 & 50 & 100 & 10 & 50 & 200 & 50 & 10 & 150 & 200 & 70 & 20 & 200 & $<300$ & 20,000 \\
\hline 34 & $\begin{array}{l}\text { Middle- } \\
\text { Fourth Lake. }\end{array}$ & 500 & $<20$ & 100 & 10 & 150 & 15 & 500 & 50 & 150 & 7 & 50 & 200 & 70 & 10 & 150 & 150 & 70 & 50 & 300 & $<300$ & 15,000 \\
\hline 35 & $\begin{array}{l}\text { Fourth Lake near } \\
\text { confluence. }\end{array}$ & 500 & 20 & 70 & 15 & 100 & 15 & 150 & $<50$ & 30 & 3 & 50 & 70 & 50 & 2 & 300 & 20 & 100 & 15 & 70 & $<300$ & 7,000 \\
\hline 36 & 117.0 & 500 & 30 & 70 & 30 & 70 & 15 & $<100$ & $<50$ & 20 & $<3$ & 30 & $<10$ & 50 & .5 & 300 & $<10$ & 150 & 3 & 30 & $<300$ & 200 \\
\hline 37 & 120.0 & 500 & 30 & 70 & 30 & 70 & 15 & $<100$ & $<50$ & 20 & $<3$ & 30 & $<10$ & 30 & .5 & 300 & $<10$ & 150 & 3 & 30 & $<300$ & 200 \\
\hline 38 & $130.1 \ldots$ & 500 & 20 & 70 & 20 & 70 & 15 & $<100$ & $<50$ & 15 & $<3$ & 30 & $<10$ & 30 & .5 & 300 & $<10$ & 150 & 3 & 30 & $<300$ & 150 \\
\hline 39 & $\begin{array}{l}\text { Marys } \\
\text { River. }\end{array}$ & 700 & 50 & 150 & 70 & 100 & 15 & $<100$ & $<50$ & 20 & $<3$ & 70 & $<10$ & 30 & $<.5$ & 150 & $<10$ & 200 & 3 & 30 & $<300$ & 150 \\
\hline & 141.3 & 500 & 70 & 70 & 30 & & & $<100$ & $<50$ & 70 & $<3$ & 50 & $<10$ & 30 & .5 & 300 & $<10$ & 150 & 3 & 30 & $<300$ & 150 \\
\hline 41 & 161.2 & 500 & 100 & 70 & 30 & 70 & 15 & $<100$ & $<50$ & 70 & $<3$ & 50 & $<10$ & 30 & $<.5$ & 500 & 15 & 150 & 3 & 30 & $<300$ & 150 \\
\hline 42 & 178.1 & 500 & 200 & 70 & 20 & 70 & 15 & $<100$ & $<50$ & 50 & $<3$ & 30 & $<10$ & 30 & $<.5$ & 500 & $<10$ & 150 & 3 & 30 & $<300$ & 200 \\
\hline 43 & 185.3 & 300 & $<20$ & 30 & 15 & 70 & 15 & $<100$ & $<50$ & 100 & $<3$ & 30 & $<10$ & 20 & $<.5$ & 200 & $<10$ & 100 & 3 & 30 & $<300$ & 200 \\
\hline 44 & Coast Fork & 300 & 30 & 50 & 20 & 100 & 15 & $<100$ & $<50$ & 70 & $<3$ & 20 & $<10$ & 30 & $<.5$ & 150 & $<10$ & 150 & 3 & 30 & $<300$ & 200 \\
\hline
\end{tabular}

${ }^{1}$ Emission spectroscopy includes metals contained in crystal lattices. Analyses by Ray G. Havens.

${ }^{2}$ Not determined. 
TABLE 15.-Uses and sources of selected trace metals

Metal

Use or source

Arsenic

(n)

Coal, petroleum, detergents, pesticides, dyes and pigments, pottery and porcelain, wood preservation, glass industry, dye and tanning industry, various chemical production industries.

Cadmium

Batteries, tires, motor oils, heating oils, paints, plastics, coal, water mains and pipes, photography, various chemical production industries.

Chromium

Alloys, refractories, catalysts, photography, paints, bacteriocides, electroplating industry, pulp and paper mills, dye and tanning industry.

Copper

Ink manufacturing, dyes and pigments, electroplating industry, pharmaceutical industry, textile industry, tanning industry, various chemical production industries.

Lead

Batteries, dyes and paints, auto exhaust, photography, textile plants.

Mercury

Coal, fungicides, electrical batteries, embalming, ink manufacturing, electroplating industry, pharmaceutical industry, pulp and paper mills, dye and tanning industry, textile plants, various chemical production industries.

Silver

Photography, alloys.

Zinc

Embalming, wood preservation, water mains and pipes, paints, electroplating industry, pulp and paper mills, dye and tanning industry, various chemical production industries. 

